American University Washington College of Law

Digital Commons @ American University Washington College of

Law

Articles in Law Reviews \& Other Academic Journals

Scholarship \& Research

2003

Alternative Approaches to Judicial Review of Social Security

Disability Cases

Jeffrey Lubbers

Follow this and additional works at: https://digitalcommons.wcl.american.edu/facsch_lawrev

Part of the Administrative Law Commons, Disability Law Commons, Judges Commons, and the Social Welfare Law Commons 
March 18, 2002

We are pleased to transmit the enclosed report by Paul Verkuil and Jeffrey Lubbers, titled Alternative Approaches to Judicial Review of Social Security Disability Cases. This year Social Security's disability programs will account for nearly five percent of the Federal budget, about $\$ 100$ billion. Nearly 10 million people depend upon them for benefits. They deserve the close attention of policy makers and the public.

The current arrangements for handling disability claims and appeals are in dire need of reform. As we stated in our January 2001 report, Charting the Future of Social Security's Disability Programs: The Need for Fundamental Change, Social Security's multi-step disability claims and appeals system is currently overwhelmed and in critical condition. The need for reform will become even more acute as the baby boomers reach the age of increased likelihood of disability and the number of applications grows substantially.

Over the last decade, the number of disability cases being appealed to the Federal district courts has increased rapidly, from about 7,000 in 1991 to about 16,000 in 2001, and it is expected to continue to grow. There are now more than 30,000 disability cases pending in the courts.

The report by Professors Verkuil and Lubbers was written under contract with the Board. It analyzes the advantages and disadvantages of two major proposals for change that have been made over the years: to create a new Article I Social Security Court with Article III review limited to legal and constitutional issues, or, to maintain the current district court review structure but centralize court of appeals review in a special Article III court (a Social Security Court of Appeals). The authors conclude that, on balance, an Article I review structure would produce real improvements in the system of administrative justice.

Professors Verkuil and Lubbers are distinguished scholars who have studied Social Security's disability determination process for many years. Their report is an informed and thoughtful contribution to the broad discussion that needs to take place if comprehensive and fundamental changes in the disability programs are to be made. Although the Board has taken no definitive position at this time on the issues analyzed in this report, we strongly believe they deserve urgent attention. 


\section{Alternative Approaches to Judicial Review of Social Security Disability Cases}

A Report to the Social Security Advisory Board

By Paul Verkuil and Jeffrey Lubbers

March 1, 2002

Contract No. SSA-RFG-02-0026

Strategem, Inc.

1111 Lincoln Rd.

Miami Beach, FL 33139

P. Verkuil, Principal Investigator 


\section{About the Authors}

Paul Verkuil and Jeffrey Lubbers are long-time students of the SSA disability decision process. Professor Verkuil, currently a Visiting Professor at the University of Pennsylvania Law School, was a participant in an early study of the SSA hearings and appeals process. ${ }^{1}$ Professor Lubbers, now a Fellow in Law and Government at American University's Washington College of Law, worked on these issues as research director of the Administrative Conference United States ("ACUS"). Both were principal co-authors of the 1992 ACUS study on the Federal Administrative Judiciary. ${ }^{2}$

They maintain an active interest in the administrative law field through teaching and research. Professor Verkuil has co-authored a leading treatise, Administrative Law and Process ( $3 \mathrm{~d}$ ed.) (Foundation Press, 1999), and Professor Lubbers has written $A$ Guide to Federal Agency Rulemaking (3d ed.) (ABA Book Publishing 1998). They are both participants in a major project of the ABA Section of Administrative Law and Regulatory Practice to restate the entire field of administrative law. ${ }^{3}$

\footnotetext{
1 See Jerry L. Mashaw, Gharles L. Goetz, Frank I. CoOdman, WARren F. Schwartz, Paul R. VERKUIL \& MilTON M. CARROW, SOCIAL SECURITY HEARINGS AND APPEALS (Lexington 1978) (This study was done through the National Center for Administration Justice, Milton Carrow, Director, and was led by Professor Mashaw of the Yale Law School.)

2 Paul R. Verkuil, Daniel J. Gifford, Charles H. Koch Jr., Richard J. Pierce Jr., \& Jeffrey Lubbers, The Federal Administrative Judiciary, 1992 ACUS 771. See also Paul R. Verkuil, Reflections upon the Federal Administrative Judiciary, 39 UCLA L. REV 1341 (1992) and Jeffrey S. Lubbers, The Federal Administrative Judiciary: Establishing an Appropriate System for Performance Evaluation of ALJs, 7 ADMIN. L.J. AM U. 589 (1994).

${ }^{3}$ See http://www.abanet.org/adminlaw/apa/home.html.
} 


\section{Table of Contents}

I. Introduction.

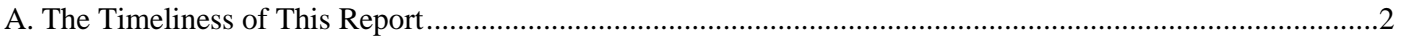

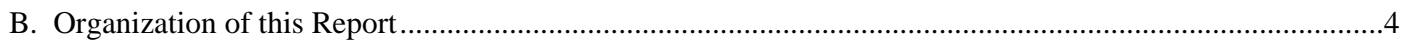

II. Overview of the Current SSA Disability Review Structure ........................................................................



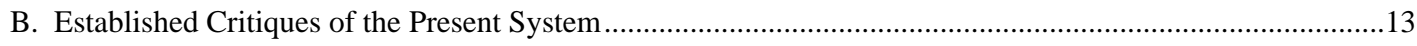

III. Some History With Respect to Proposals for Specialized Courts ......................................................................15

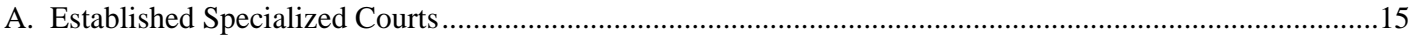

B. Other Recent Proposals for Specialized Courts Relating to Social Security .............................................21

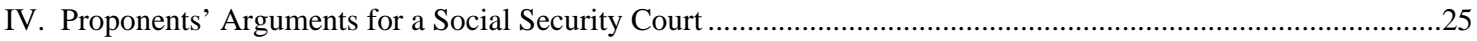

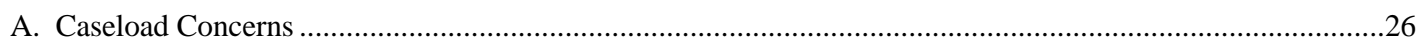

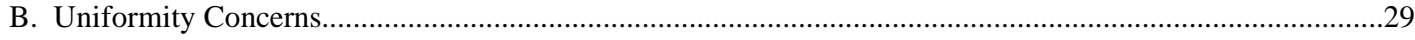

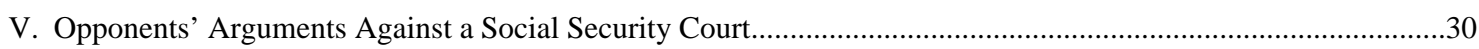

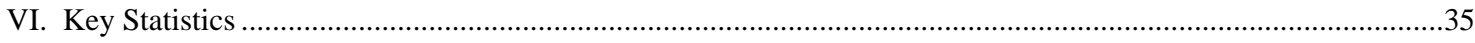

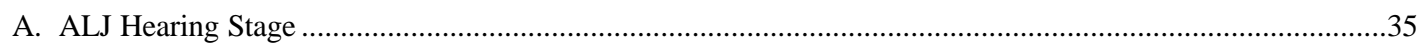

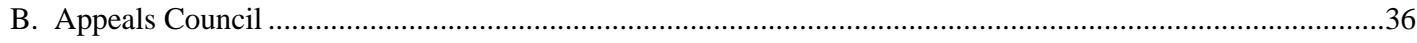

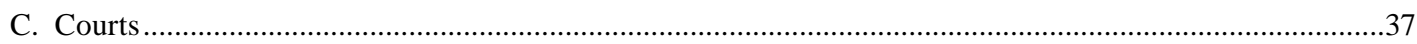



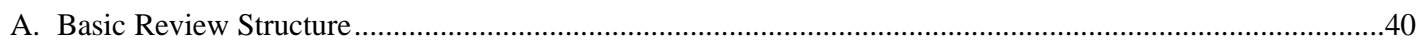

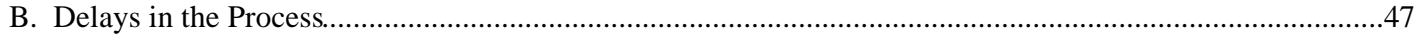

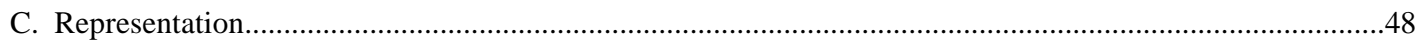

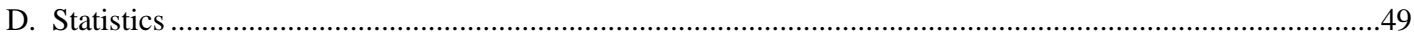

E. Lessons Learned from the Veterans Benefits Appeals Process..............................................................51

VIII. An International Comparison—The Australian Social Security Appeals Tribunal.........................................53

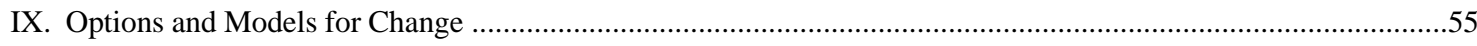

A. Administrative Changes-With No Changes Above the Appeals Council Level .....................................55

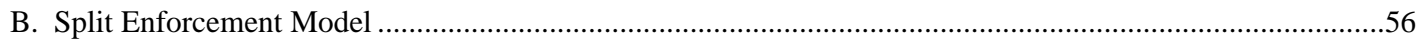

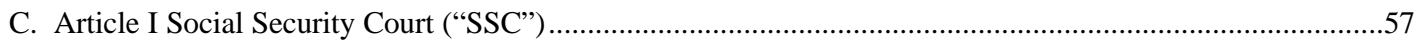

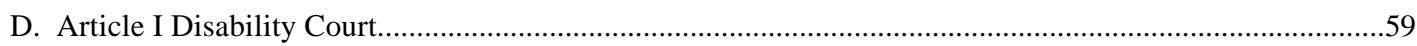

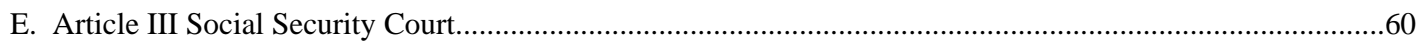

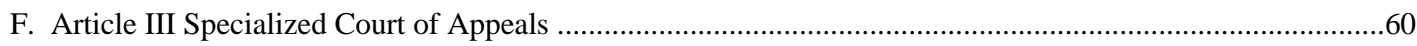

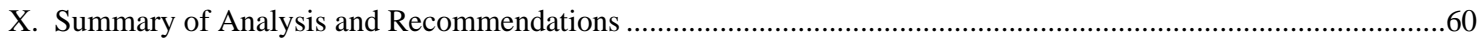

A. Pros and Cons of the Present Review System and Alternatives ..............................................................55

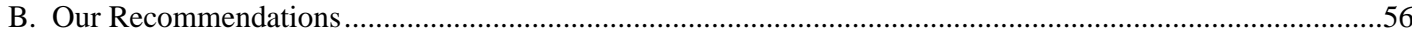

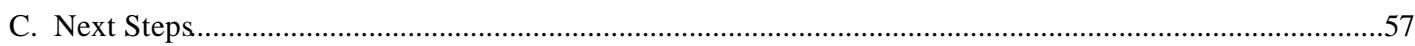

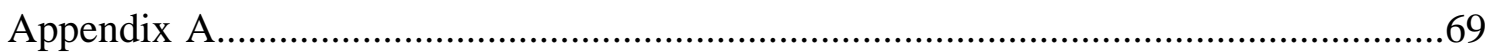

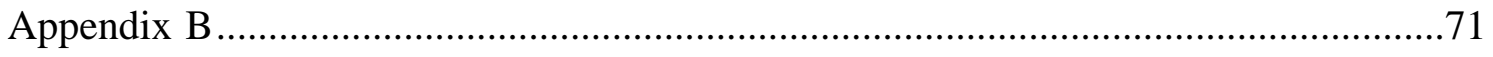




\title{
Alternative Approaches to Judicial Review of Social Security Disability Cases
}

\author{
A Report to the Social Security Advisory Board \\ By Paul Verkuil and Jeffrey Lubbers*
}

\section{$\underline{\text { I. Introduction }}$}

This Report was commissioned by the Social Security Advisory Board ("SSAB"). ${ }^{4}$ Its goal is to evaluate various proposals for changes in the judicial review structure relating to Social Security disability determinations. These proposals have emanated from Congress, federal court advisory bodies, knowledgeable observers, agency officials, and academics. SSA's own Disability Advisory Committee in 1989 recommended that a study be done concerning "possible alternatives to the present method of court review of Social Security cases." At least two contrasting legislative proposals have been pending for several years that span the range of realistic possibilities: one would change the review structure after the ALJ stage by creating a new Article I court structure (a Social Security Court) with Article III review limited to legal and constitutional issues; another would maintain the current district court review structure but centralize court of appeals review in a special Article III court (a Social Security Court of Appeals).

\footnotetext{
* The authors would like to thank Owen Kendler, Class of 2002, University of Pennsylvania Law School, for his excellent research assistance, particularly with respect to the veterans claims appeals process.

${ }^{4}$ Contract \# SSA -REG-02-0026.

${ }^{5}$ REPORT OF THE DISABILITY ADVISORY COMMITTEE TO THE COMMISSIONER OF SOCIAL SECURITY (July 25, 1989) 15, 19 (reiterating a recommendation it made in March 1988 that the Department of Justice prepare such a study).
} 


\section{A. The Timeliness of This Report}

While these alternatives are not themselves new, they have become increasingly relevant in light of recent events. The number of disability claims is expected to rise in the future for several reasons: (1) the impending retirement of Baby Boomers, ${ }^{6}$ (2) the downturn of the economy in the last two years, ${ }^{7}$ (3) the resumption of continuing disability reviews ("CDRs") by the $\mathrm{SSA}^{8}{ }^{8}$ and (4) the increasing tendency of private insurance companies to require as a condition of payments that claimants pursue their offsetting SSA disability benefits. ${ }^{9}$ These caseload realities create pressure on the SSA to achieve more uniform, fair, and efficient decisionmaking and will eventually add to the caseload of the federal courts on judicial review. By the mid-1990s, several studies of the federal judiciary had indicated that alternatives to the increasing federal caseload

\footnotetext{
${ }^{6}$ See Statement of Stanford G. Ross, Chairman Social Security Advisory Board at the Tenth National Educational Conference, Association of Administrative Law Judges (Oct. 3, 2001) ("SSA actuaries project continued rapid growth as the baby boomers reach the greater likelihood of disability."); SSAB, A GENDA FOR SOCIAL SECURITY: CHALLENGES FOR THE NEW CONGRESS AND THE NEW ADMINISTRATION, at 1, 2, 16 \& 37 (Feb. 2001), available at http://www.ssab.gov/Overview1.pdf. Baby Boomers will begin to reach the age of 65 in 2011 and finish reaching 65 in 2030. When they begin to retire in 2011, there will be 40.4 million seniors (or 13 percent of the population) and will grow to 70.3 million (20 percent of the population) by 2030. See Press Release, U.S. Census Bureau, Census Bureau Projects Doubling of Nation's Population by 2100 (Jan. 13, 2000).

${ }^{7}$ It is well known that while the disability program is not an employment scheme, applications rise when the economy falters.

${ }^{8}$ The SSA is currently in its seven-year CDR plan, commenced in 1996. The plan is part of the agency's response to the Government Performance and Results Act of 1993, Pub. L. No. 103-62. It calls for increasing annual CDRs from 603,000 in 1997 to 1.7 million in 2002 with a peak year of 1.8 million in 2000. See OFFICE OF InSPECTOR GENERAL, SOCIAL SECURITY AdMINISTRATION, REPORT \# A-01-9991002, AUdiT REPORT: PERFORMANCE MEASURE REVIEW: RELIABILITY OF THE DATA USED TO MEASURE CONTINUING DISABILITY REVIEWS (June 2000), at A-5-A-6. Our report takes no position on revisions to the CDR program.

${ }^{9}$ Cf. D. Gregory Rogers, The Effects of Social Security Awards on Long-Term Disability Claims, 1 ATLA ANNUAL CONVENTION REFERENCE MATERIALS 1117, 1117 (July 2001). Conversations with the SSAB have also created a suspicion that private insurance policies are beginning to require appeals through the ALJ stage before payment of insurance benefits, but the situation is too recent for data to have been compiled.
} 
should be sought. ${ }^{10}$ While the district court caseload only represents a small segment of total SSA disability cases, it is a significant and growing portion of the federal courts' civil case workload. ${ }^{11}$

In addition, during the last decade, a possible model for Article I/Article III shared review of disability cases has become reality with the emergence of a program for review of the Department of Veterans Affairs ("VA") disability claims. The presence of an operating Article I disability court structure, the Court of Appeals for Veterans Claims makes it possible now to actually compare alternative disability review systems. ${ }^{12}$ Finally, in 1994, Congress also made a significant structural change in the social security program, by separating SSA from the Department of Health and Human Services to "ensure that "policy errors resulting from inappropriate influence from outside the agency such as those occurring in the early 1980s do not recur in the future.",13 As a result, the agency is now independent and better able to assist in a restructuring of the process.

\footnotetext{
${ }^{10}$ See Judicial Conf. OF THE United States, LONG RANGe Plan FOR THE Federal Courts 33 (Dec. 1995); see also COMM. ON STRUCTURAL ALTERNATIVES FOR THE FEDERAL COURTS OF APPEALS 65 (Oct. 1998); RECOMMENDATIONS OF THE ADMINISTRATIVE CONFERENCE OF THE UNITED STATES (1992), at http://www.law.fsu.edu/library/admin/acus/305877.html.

${ }^{11}$ In the fiscal year ending September 30, 1999, SSA disability cases constituted 4.6 percent of all federal civil cases terminated through court action, while in the period ending March 31, 2001, SSA disability cases constituted 6.0 percent of such cases. Compare ANNUAL REP. OF THE DIR., JUDICIAL BUSINESS OF THE UNITED STATES COURTS 1999 at Table C-4, 160-61 (1999) (reporting that 13,454 social security cases terminated out of 228,190 terminated civil cases), at http://www.uscourts.gov/judbus1999/supps.html; with Admin. OfFice OF THE U.S. COURTS, Federal Judicial CASElOAd STATiSTiC [SIC], Table C-4 (Mar. 31, 2001) (12,646 of 207,087 terminated civil cases), available at http://www.uscourts.gov /caseload2001/tables/c04mar01.pdf.

${ }^{12}$ Prior to 1988 , VA disability decisions were unreviewable by statute: "[All decisions] shall be final and conclusive on all questions of law and fact, and no other official or court of the United States shall have jurisdiction to review by mandamus or otherwise any such decision." Act of March 20, 1933, ch.3, § 5, 48 Stat. 8, 9 (repealed and superseded by Pub. L. No. 85-86, 71 Stat. 167) (cited by WILliAM F. FOX, THE United STATES BOARD OF VETERANS' APPEALS: THE UNFINISHED STRUGGLE TO RECONCILE SPEED AND JUSTICE DURING INTRA-AGENCY REVIEW 19 (2000)).

${ }^{13}$ Statement by Rogelio Garcia, Congressional Research Service, House Subcommittee on Social Security, pp. CRS-4-CRS-5 (July 25, 1996), quoting H. REP. No. 103-670, Social Security Administration Reform Act of 1994, 103rd Cong. p. 90 (1994), as cited by ASS'N OF ADMIN. LAW JUDGES, REPORT AND RECOMMENDATIONS FOR THE TRANSFER OF THE AUTHORITY TO MAKE FINAL ADMINISTRATIVE
} 
For all these reasons, a study of judicial review alternatives is timely and potentially more productive than it has been at any time in the recent past. While there has not been any legislation introduced since 1995, this Report could well serve as an analytical predicate to renewed congressional interest.

\section{B. Organization of this Report.}

This Report will proceed as follows: First, it analyzes the existing SSA disability review structure with its strengths and weaknesses; next it analyzes various alternatives for judicial review, along with an evaluation of the VA disability review structure; finally, this Report compares the proposed alternatives against the existing SSA structure and makes recommendations, where feasible. It concludes by suggesting areas for further study.

It is important to note that this Report is primarily a study of the appeals process, whether it be Article III or Article I based. The Report will not deal at length with the administrative decision structure at SSA below the Appeals Council stage. It recognizes that the greatest potential for meaningful reforms in the SSA process occur in the intake, reconsideration, and hearing stages when the caseload is the highest. But our mandate is to take the hearing caseload level as a given, and to describe alternatives in the final stages of review - at the Appeals Council and judicial review level. Accordingly,

AdJUdiCATIONS OF SOCIAL SECURITy ACT ClAIMS FROM THE SOCIAL SECURITY ADMINISTRATION TO A NEW INDEPENDENT REGULATORY AGENCY 5 (Jan. 2001), available at http://www.aalj.org/sepplan.html [hereinafter REPORT ON NEW INDEPENDENT REGUlATORY AGENCY]. See also Statement of Ronald G. Bernoski, President, Association of Administrative Law Judges Before the House Subcomm. on Social Security, Comm. on Ways and Means, Hearing on the Social Security Disability Programs' Challenges and Opportunities (June 28, 2001), available at http://www.aalj.org/sepplan-statement.doc. The "inappropriate influence" referred to includes the targeting of ALJs with high allowance rates for special review and training during the Reagan Administration. The program was held to be improper (and then withdrawn by SSA) after an ALJ organization challenged it in Association of Administrative Law Judges, Inc. v. Heckler, 594 F. Supp. 1132 (D.D.C 1984). See Richard E. Levy, Social Security Disability Determinations: 
although the Report does explore the role of the administrative law judges as part of a possible move to an Article I alternative court structure, many other important questions, including the role of state deciders in the current process ${ }^{14}$ and the need for better quality assurance systems ${ }^{15}$ will be left for further study. ${ }^{16}$

It should be noted that, with respect to many of these questions, the authors urge that the many recommendations of the Administrative Conference of the United States (ACUS) be considered. ACUS undertook numerous studies relating to the appeals process in the Social Security Administration (SSA) disability program. It issued four recommendations specifically involving the various levels of review in that program. ${ }^{17}$ In Recommendation 87-6, State-Level Determinations in Social Security Disability Cases, ACUS addressed the first level of determination and review in the disability program. The underlying study was based on early results from demonstration projects

Recommendations for Reform, 1990 B.Y.U. L. Rev. 461, 497-502 (detailing SSA's controversial practices with respect to its ALJs).

14 See, e.g., GAO, SOCIAL SECURITY DiSABILITY: SSA MUST HOLD ITSElF ACCOUNTABLE FOR CONTINUED IMPROVEMENT IN DECISION-MAKING, GAO/HEHS-97-102 (Aug. 1997). See also REPORT OF THE DISABILITY ADVISORY COMMITTEE TO THE COMMISSIONER OF SOCIAL SECURITY, supra note 2 at 17, (urging changes in the DDS process).

15 See, e.g., The Lewin Group, Pugh ETtinger MCCARTHy Associates, \& CORNELl University, EVALUATION OF SSA'S DISABILITY QUALITY ASSURANCE (QA) PROCESSES AND DEVELOPMENT OF QA OPTIONS THAT WILl SUPPORT THE LONG-TERM MANAGEMENT OF THE DISABILITY PROGRAM, (Mar. 16, 2001).

${ }^{16}$ This Report primarily covers cases involving disability under the Disability Insurance program (Title II of the Social Security Act) and the Supplemental Security Income (SSI) program (Title XVI), which accounts for 90 percent of the work of SSA's Office of Hearings and Appeals. The remainder consists of claims made under the Retirement and Survivors Insurance program (Title II), Medicare (Title XVIII), and non-disability claims under the SSI program. See About SSA's Office of Hearings and Appeals, available at http://www.ssa.gov/oha/overview.htm. Appeals under Medicare Parts A and B constituted about $11 \%$ of the hearing dispositions by SSA ALJs in FY 2000. See Soc. Sec. Admin., Social Security Bulletin, ANNUAL STATISTICAL SUPPLEMENT 117, Table 2.F9 (2000). Because these Medicare cases are now being heard under an agreement with the Department of HHS, we take no position on whether they should necessarily be treated in the same way as disability cases, if our recommendations are followed.

17 These recommendations can be found at "Recommendations of the Administrative Conference of the United States," available at http://www.law.fsu.edu/library/admin/acus/acustoc.html. Professor Verkuil was a member of ACUS and Professor Lubbers was ACUS's Research Director from 1982-95. ACUS's operations ceased in October 1995. See Symposium in 30 ARIZ. ST. L.J. 1-204 (1998). 
involving the state-level disability determination process. It recommended additional experimentation with face-to-face hearings and interviews at this level.

\section{Recommendation 78-2, Procedures for Determining Social Security Disability}

Claims,${ }^{18}$ primarily addressed the administrative law judge stage of the Social Security disability program. It recommended the continued use of ALJs, and made suggestions concerning the development of the evidentiary hearing record, including recommending that ALJs take more care in questioning claimants, seek to collect as much evidence prior to the hearing as possible, make greater use of prehearing interviews, and make better use of treating physicians as sources of information. It also recommended closing of the record at the ALJ stage and better development and dissemination of precedent materials by the SSA.

Recommendation 87-7, A New Role for the Social Security Appeals Council, ${ }^{19}$ addressed the organization and function of the Appeals Council. ACUS suggested wideranging and substantial changes in the workings of the Appeals Council, including that it move away from its historical primary function as a case review panel. The recommendation suggested that the caseload be significantly limited, and that the Appeals Council focus on important issues on which it could issue precedential opinions.

In Recommendation 90-4, Social Security Disability Program Appeals Process: Supplementary Recommendation, ${ }^{20}$ the Conference addressed the need to have the

\footnotetext{
1843 Fed. Reg. 27,508 (June 26, 1978). This recommendation was based largely on JERRY L. MASHAW, Charles L. Coetz, Frank I. Godman, WARren F. Schwartz, Paul R. Verkuil \& Milton M. CARROW, SOCIAL SECURITY HEARINGS AND APPEALS (Lexington 1978) [hereinafter MASHAW ET. AL.]. (This study was done through the National Center for Administration Justice, Milton Carrow, Director, and was led by Professor Mashaw of the Yale Law School.)

1952 Fed. Reg. 49,143 (Dec. 30,1987).

${ }^{20} 55$ Fed. Reg. 34,213 (Aug. 22, 1990).
} 
evidentiary record be as complete as possible as early in the process as possible. It advocated an increased use of subpoenas to make this possible, and in conjunction with a provision in an earlier Recommendation, that physicians asked to provide medical information in disability proceedings be adequately compensated. ${ }^{21}$ The Conference also reiterated that the record before the ALJ should be closed at a set time after the hearing. The recommended procedure would give the claimant sufficient time to acquire such information as is needed to complete the record, and would also provide for extensions of time upon a showing of good cause. As a corollary to this, the Conference urged that a procedure be developed for the ALJ to reopen a record upon petition by the claimant where there is new and material evidence relating to the period covered by the hearing. ${ }^{22}$

\section{Overview of the Current SSA Disability Review Structure}

The current judicial review structure has been in place since the beginning of the program. ${ }^{23}$ In terms of administrative review, it is unique in its scope and workload. No

\footnotetext{
${ }^{21}$ See ACUS Recommendation 89-10, Improved Use of Medical Personnel in Social Security Disability Determinations, I5(c), 55 Fed. Reg. 34,212 (Aug. 22, 1990). This recommendation also urged enhanced use of medical personnel at the initial decision level, better identification of conflicts over medical evidence, and heavier reliance on medical experts at the ALJ stage. It also suggested that if these reforms were instituted, the initial determination level should be a single step-with the elimination of the separate reconsideration stage.
}

${ }^{22}$ Such petitions could be filed within one year of the ALJ decision or while the case is pending before the Appeals Council if it has been appealed. Under such a procedure, new evidence would be considered first by the ALJ, thereby giving the adjudicator most familiar with the case the first opportunity to review new evidence, potentially reducing the number of cases that would be presented to the Appeals Council, and giving the Appeals Council more of an appellate role. $I d$.

${ }^{23}$ Federal district court review of all Social Security decisions in which the Commissioner of Social Security was a party has been available since the SSA was created in 1935. See 42 U.S.C. $\S 405,42$ Stat. 624 (Aug. 14, 1935). ALJs (formerly designated as hearing examiners) were used from the inception of the DI program in 1956. Due to the mounting caseload, the Office of Hearings and Appeals was created in 1959. When the SSI program was federalized and added to the SSA in 1972, it used the existing SSA disability appeals system. In cases involving termination of benefits, SSA's practice was to offer only an informal pre-termination hearing, followed by a formal post-termination hearing before an ALJ, see Mathews v. Eldridge, 424 U.S. 319, 346 (1976) (upholding this process against a due process challenge). However, Congress provided for pre-termination ALJ hearings in 1983, see 42 U.S.C. § 423(g), added by Pub. L. No. 97-455 (1983). See also Soc. SeC. Admin. OnLine, DetAiled Chronology, available at http://www.ssa.gov /history/chrono.html (last visited Feb. 8, 2002) and Daniel J. Gifford, Federal 
other program of the federal government produces such a large and complicated caseload for the federal courts to review, and of course no other benefit program of the federal government serves over 10 million beneficiaries or involves expenditures that will top $\$ 100$ billion in FY 2002. ${ }^{24}$

\section{A. The Role of the District Court}

After the Social Security Administration signs off on a disability case, either as a result of an ALJ decision or Appeals Council consideration, the losing claimant has an opportunity to appeal to the federal district court. While traditionally known as a trial court, the federal district court serves an appellate function in SSA disability review. In this role, it is called upon not to hear matters in a trial de novo as it traditionally does, ${ }^{25}$ but to apply the substantial evidence standard to the record before it. ${ }^{26}$ Over the years, substantial evidence reviews of disability cases by district courts (and even subsequent review of such decisions by courts of appeals) have remained a heavily contested matter. $^{27}$

This modification of the role of district courts is made necessary because of the size of the disability caseload, which makes the usual practice of direct review of formal

\footnotetext{
Administrative Law Judges: The Relevance of Past Choices to Future Directions, 49 ADMIN. L. REV. 1, 14 19 (1997) (providing a concise history of the SSA appeals legislation).

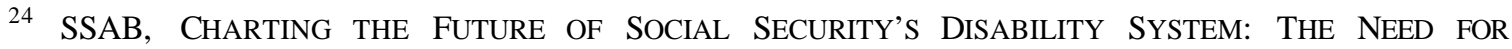
FUNDAMENTAL CHANGE 1 (Jan. 2001) [hereinafter SSAB, CHARTING THE FUTURE], at http://www.ssab.gov /disabilitywhitepap.pdf.

${ }^{25}$ The district courts do hear other miscellaneous appeals from agencies because, under the Administrative Procedure Act, the venue for judicial review of agency action is controlled by the underlying programmatic statute. If the statute is silent on the matter, judicial review is only available through a suit for injunctive or declaratory relief in the appropriate district court. See 5 U.S.C. § 703.

${ }^{26}$ See 42 U.S.C. $\S 405 \mathrm{~g}$ (commonly referred to as Social Security Act $\S 205(\mathrm{~g})$ ), available at http://www.ssa.gov/OP_Home/ssact/title02/0205.htm.

${ }^{27}$ See, e.g., Davis v. Callahan, 125 F.3d 670, 675-76 (8th Cir. 1997) (Beezer, J. dissenting) (stating that the ALJ's denial of benefits was clearly supported by substantial evidence).
} 
administrative adjudication in the courts of appeals manifestly impractical. ${ }^{28}$ For example, during the decade 1990 to 2000, the number of new disability cases in the federal courts nearly tripled from 5,000 to $15,000,{ }^{29}$ while during this period the disability caseload in the courts of appeals varied far less greatly, going from 992 appeals in $1988^{30}$ to 754 appeals in $2001 .^{31}$ In terms of impact upon the court system, during the one-year period ending September 30, 2000, Social Security cases represented 5.86 percent of all civil district court cases, but only 2.5 percent of all civil cases in the courts of appeals. ${ }^{32}$ But if one assumed that disability cases went directly to the courts of appeals during this period, they would have represented a backbreaking 19.6 percent of the appeals courts' civil caseload. ${ }^{33}$

Federal district courts play a significant symbolic role as well as a corrective one in our judicial system. For social security disability claimants, access to the federal courts helps to legitimate their claims. As an earlier study of the SSA disability system observed, review by a judge of broad competence guarantees a fresh and independent

\footnotetext{
${ }^{28}$ See MASHAW ET AL., supra note 15 at 125 . Most statutes establishing formal agency adjudicative programs specify that judicial review is by the courts of appeals because a trial-type hearing has already been held before an agency adjudicator, and review is to be had on the basis of the administrative record below. However, due to the high volume of SSA disability cases, review is placed in the district court in the first instance. See generally David Currie \& Frank Goodman, Judicial Review of Federal Administrative Action: Quest for the Optimum Forum, 75 COLUM. L. REV. (1975).

29 See SOCIAL SECURITY ADVISORY BOARD, DISABILITY DECISION MAKING: DATA AND MATERIALS 84 (Jan. 2001) [hereinafter SSAB, DSABILITY DECISION MAKING]; ANNUAL REP. OF THE DIR., JUDICIAL BUSINESS OF THE UNITED STATES COURTS 2000 [hereinafter JUDICIAL BUSINESS 2000] at Table S-17 (2000) available at http://www.uscourts.gov/judbus2000/contents.html (displaying data for 1990 and 1996 through 2000).

${ }^{30}$ RePorts of the ProceEdings OF THE JUdicial COUNCIL, U.S. AdMINISTRATIVE OFFICE OF THE U.S. COURTS: REPORT 1988 at Table B1-A (1988) [hereinafter REPORT 1988].

${ }^{31}$ See ANNUAL REP. OF THE DiR., JUdiCIAL BUSINESS OF THE UNITED STATES COURTS 2001 at Table B-7 (2001) (displaying data for the twelve month period ending March 31, 2001) [hereinafter JUDICIAL BUSINESS 2001].

32 See JudiCiAl Business 2000, supra note 26, at Tables B1-A \& C-4 (2000), (942 of 37,336 civil terminations for the fiscal year ending September 30, 2000).
} 
look at the disability decision process. $^{34}$ Federal courts are in principle the best assurance we have that a citizen will be treated fairly.

But over the years the theoretical advantage of judicial oversight has become more limited in practice. District judges increasingly review disability cases not by themselves, but through established surrogates: magistrate judges take evidence, decide on summary judgment, or remand to the agency. ${ }^{35}$ In FY 1999, magistrates decided over 40 percent of disability cases. ${ }^{36}$

While the use of magistrate judges is well accepted in this and other contexts, they are in fact Article I rather than Article III deciders. ${ }^{37}$ They are often called upon to perform routine matters (like overseeing discovery disputes) or to make decisions in situations with repetitive fact patterns, like SSA disability cases. They are in effect administrative deciders within the Article III system. Indeed, in terms of selection

\footnotetext{
${ }^{33}$ See id. at Tables B1 \& C-4.

${ }^{34}$ See MASHAW ET AL. supra note 15 , at 139.

${ }^{35}$ Technically, the magistrate recommends a course of action to the district judge and the district judge has discretion as to whether to sign and enter the decision. See 28 U.S.C. § 636(b)(1)(B). Magistrate judges hear SSA matters under 28 U.S.C. $\S 636(\mathrm{~b})(1)(B)$. The statute allows a district judge to assign cases to magistrate judges to conduct hearings and to submit to the judge proposed findings of fact and a recommendation for the disposition in the case. Any party has ten days to ask the judge to review the magistrate judge's findings and recommendations de novo. The recommendations may accept, reject or modify the magistrate judge's report in whole or in part.

${ }^{36}$ Magistrate judges disposed of 6,132 social security cases in FY 1999 and 5,516 in FY 2000. This is out of a total of 15,537 social security terminations in FY 1999 (39.4 percent) and 14,731 in FY 2000 (37.4 percent). This is down from 54.6 percent in 1988. See JUDICIAL BUSINESS 2000, supra note 26,Table S-17, available at http://www.uscourts.gov/judbus2000/tables/s17sep00.pdf.; ANNUAL REPORTS for 1999 and 2000 supra note 26, Table C-4; REPORT 1988, supra note 27, at Table C-4.

37 It may be more apt to identify U.S. Magistrate Judges as "Title 28 Judges." While they are agents of Article III judiciary, magistrate judges are not themselves Article III judges. Congress has authorized the Judicial Conference of the United States to determine the salary and number of magistrate judges in each district. A magistrate judge's salary can be no more than 92 percent of a district courts judge's salary. Once the required number is established, each of the 97 federal districts hire magistrate judges by a majority vote of the judges in the district. Full-time magistrate judges serve eight-year terms and can be rehired for additional terms until the age of seventy. See 28 U.S.C. $\S \S 631,633,634,636$, 637; see also United States v. Raddatz, 447 U.S. 667, 682-83 \& n.11 (1980) (analogizing magistrate judges to special masters and distinguishing them from Article III judges).
} 
criteria and experience, magistrates are not that far removed from ALJs, ${ }^{38}$ and there are not many functional differences between the two corps of administrative deciders. Since the district court applies the substantial evidence test, SSA cases rarely go to trial. In 2001 , only 0.25 percent of disability cases reached oral arguments in district court, ${ }^{39}$ which is about the same as the 0.31 percent in $1988 .^{40}$

In applying the substantial evidence test, district courts are in theory bound to affirm an agency's findings of facts if there is some support in the record for the agency's position. Under the familiar APA standard, substantial evidence is defined as more than a "scintilla," which must be found after consideration of the whole record. ${ }^{41}$ This standard is meant to be very deferential, ${ }^{42}$ although ALJ decisions on witness and physician credibility remain part of the equation.

\footnotetext{
38 If anything, the qualifications and protections for ALJs are stronger than for magistrate judges. Magistrate judges are appointed for a term of eight years while ALJs do not have a term. Magistrate judges must be a member in good standing of the bar for five years to be eligible; ALJs for seven years. Magistrate judges are appointed by district court merit selection panels, composed of residents of the individual judicial districts; ALJs are appointed by agencies off a list of qualified eligible applicants after an examination by the Office of Personnel Management. Removal of magistrate judges by the judges during the term of office must be only for incompetence, misconduct, neglect of duty, or physical or mental disability. ALJs may be disciplined or removed only for "good cause" demonstrated before the Merit Systems Protection Board. See 28 USCA $\S 631$ (magistrate judges) and 5 U.S.C. $\S 7521 ; 5$ CFR $\S$ 930.203a; and "USA Jobs: Administrative Law Judges," available at http://www.usajobs.opm.gov/EI28.htm (AUs).

${ }^{39}$ See JUDICIAL BUSINESS 2001 supra note 28, at Table C-4. This is one tenth of the percentage of all civil cases (2.3 percent) that went to trial before district courts in 2001. See id.

${ }^{40}$ See REPORT 1988 supra note 27, at Table C-4.

${ }^{41}$ See Universal Camera Corp. v. NLRB, 340 U.S. 474, 488 (1951); NLRB v. Columbian Enameling \& Stamping Co., 306 U.S. 292, 300 (1939) ("Substantial evidence is more than a scintilla, and must do more than create a suspicion of the existence of the fact to be established."). Another oft-quoted Supreme Court formulation is "such evidence as a reasonable mind might accept as adequate to support a conclusion." Consolidated Edison Co. v. NLRB, 305 U.S. 197, 229 (1938). See ERNEST GELLHORN AND RONALD M. LEVIN, ADMINISTRATIVE LAW AND PROCESS IN A NUTSHELL 92 (4TH ED. 1997). In a subsequent case involving the SSA disability process, the Court made it clear that even evidence that would be inadmissible in court and was not subject to cross-examination before an ALJ could constitute substantial evidence. Richardson v. Perales, 402 U.S. 389 (1971).

${ }^{42}$ See KenNETH CulP DAVIS \& Richard J. PiERCE, AdMinistRATIVE LAW TREATISE $§ 11.2$ (1994).
} 
But deference is not what the statistics show in SSA cases. District courts have long reversed and remanded disability cases on a greater than 50 percent basis, ${ }^{43}$ although these rates vary greatly among judicial districts. ${ }^{44}$ It is difficult to know what this reversal/remand rate (which instead approximates what one might expect under a de novo review system) actually reflects. ${ }^{45}$ In one respect, it shows that district court judges (and magistrates) are skeptical if not antagonistic to the quality of the underlying SSA decision process, which may be due to factors that are no longer compelling. ${ }^{46}$ But it may also be the result of an unusual statutory relationship with the agency itself.

The "good cause" remand function (under section $205(\mathrm{~g})^{47}$ ) gives the district court an opportunity to exercise policy control. The remand provision places the district courts "not in the accustomed role as external overseers of the administrative process ... but virtually as co-participants in the process . . .".48 In effect, this unique standard allows (perhaps even encourages) the district courts, or their magistrate judges, to send cases back almost reflexively. Since the likelihood is that on remand the agency will

\footnotetext{
${ }^{43}$ See infra, Section V (note 113 and accompanying text).

${ }^{4}$ See infra, Appendix A (showing variations in reversal rates by judicial district with significant numbers of SSA disability cases, from 2.3 percent in the Eastern District of Kentucky to $53.8 \%$ in the Southern District of New York of judgments on the merits).

45 See Paul R. Verkuil, An Outcomes Analysis of Scope of Review Standards (forthcoming 2002).

46 See id. at 37 (discussing reactions of the courts to the controversial congressionally mandated ("Bellmon") review program which removed claimants from the disability rolls in the 1980s); see also REPORT ON NEW INDEPENDENT REGULATORY AGENCY, supra note 10.

${ }^{47}$ Social Security Act $§ 205(\mathrm{~g})$ provides in relevant part:

(g) . . . The findings of the Commissioner of Social Security as to any fact, if supported by substantial evidence, shall be conclusive, . . . . The court may, on motion of the Commissioner of Social Security made for good cause shown before the Commissioner files the Commissioner's answer, remand the case to the Commissioner of Social Security for further action by the Commissioner of Social Security . . . 42 U.S.C. 405(g).

${ }^{48}$ See MASHAW ET AL. ET AL., supra note 15, at 133.
} 
enter judgment in the claimant's favor, ${ }^{49}$ this decision of the court often becomes outcome determinative. Given this ease of remand, one would think, the present system of judicial review has incentives built-in to resolve matters quickly and without a large investment of district court time. Yet, the average time SSA cases sit before the district court is a non-expeditious twelve to eighteen months. ${ }^{50}$

\section{B. Established Critiques of the Present System}

When the judicial phase was looked at in depth twenty-five years ago, several suggestions were made to improve the process. First, it was suggested that the record should be closed after the ALJ stage; and, second, that the good cause remand option under Section $205(\mathrm{~g})$ be eliminated. ${ }^{51}$ The purpose of these relatively modest changes was to fix responsibility: "if there is ever to be agreement on whether anyone in the whole multi-tier process of disability claims adjudication has ever committed an error, there must be one locus of responsibility for developing a record and review of that record. ${ }^{, 52}$

\footnotetext{
${ }^{49}$ Remands to the Appeals Council result in grants over 60 percent of the time. See SSAB, CHARTINGthe FUTURE, supra note 21, at 14.

${ }^{50}$ Compare id. at 7 with Theodore Eisenberg \& Kevin M. Clermont, Judicial Statistical Inquiry Form: Federal District-Court Civil Case (providing a dataset that reveals an average time of 357 days in FY 2000, up from 256 days in FY 1990), at http://teddy.law.cornell.edu:8090/questcv3.htm Statistics on time for remands versus reversals and affirmances have not been recorded. The SSAB reports that it takes about one year for a claim to be processed at the ALJ level. This compares favorably to the approximately 505 days in 2001 to process an appeal by the Appeals Council. The average time to process a claim at the Appeals Process has been on a steady rise since the mid-1990s when it took just over 100 days for processing in 1994. See SOCIAL SECURITY ADVISORY BOARD, STATEMENT ON THE SUPPLEMENTAL SECURITY INCOME PROGRAM, (September 2001), at 7-8; SSAB, DisABILITY DECISION MAKING, supra note 26, at 78 (Chart 60).

${ }^{51}$ MASHAW ET AL. supra note 15, at 103, 126, 134-36. Congress would of course have to amend $\S 205(\mathrm{~g})$ in this regard.

${ }^{52}$ MASHAW ET AL. supra note 15, at 136 (emphasis in original).
} 
These changes were never implemented, but they are still worthy of consideration. $^{53}$ One virtue of a closed record would be to enhance the precedential impact of district courts review on the agency since the open file practice undermines attempts to follow a case to its conclusion. Furthermore, while the open file practice may have made some sense in an era where there was little legal assistance to work up the case at the administrative stage, today most claimants are represented by attorneys ${ }^{54}$ who can be responsible for that task. Today it seems that smart counsel for claimants are in effect encouraged to "game" the system by holding back key pieces of data (medical records, etc.) in order to gain remands at the judicial review phase. ${ }^{55}$ This tactic may delay the process unnecessarily (and may cost the claimant not only valuable time but higher attorney's fees as well). ${ }^{56}$

The 1978 study took no position on whether an Article I court alternative would be preferable to the present system for review, except to emphasize that such a body, if

\footnotetext{
53 See ACUS Recommendation 90-4 (4):

4. Closing of the Administrative Record: The administrative hearing record should be closed at a set time after the evidentiary hearing. Prior to this, the ALJ should set forth for the claimant what information the claimant needs to produce to complete the record, issue any necessary subpoenas, and provide the claimant adequate time to acquire the information. Requests for extension should be granted for good cause, including difficulty in obtaining material evidence from third parties. The ALJ should retain the discretion to accept and consider pertinent information received after closure of the record and before the decision is issued.
}

\footnotetext{
Recommendation 90-4, Social Security Disability Program Appeals Process: Supplementary Recommendation, available at http://www.law.fsu.edu/library/admin/acus/305904.html. See also REPORT OF THE DISABILITY ADVISORY COMMITTEE TO THE COMMISSIONER OF SOCIAL SECURITY, supra note 2 at $12-13,18$, (urging closure of the record at the end of the ALJ stage).

54 About 70 percent of claimants are represented before ALJs. See SSAB, DISABILITY DECISION MAKING, supra note 26, at 73 (Chart 56). These attorneys are paid approximately $\$ 500$ million annually in attorney fees by SSA. See SSAB, How SOCIAL SECURITY'S DISABILITY PROGRAMS CAN BE IMPROVED (Aug 1998) 25 (citing payments of $\$ 490$ million in FY 1997).

55 SSAB, A GENDA FOR SOCIAL SECURITY supra note 3, at 13.

56 Attorneys are paid a percentage of the claimant's retroactive benefits, which grow as the case moves through the system.
} 
created, must decide matters in a timely, independent, and professional manner. ${ }^{57}$ In the intervening years, much has happened, including the newly independent status of the SSA itself, and the case for a new approach to judicial review-or at least for renewed justification of the existing structure-is surely stronger than ever. It is to the subject of specialized courts (both Article I and Article III) that we turn next.

\section{Some History With Respect to Proposals for Specialized Courts}

Although the United States has largely turned to the generalist Article III district and circuit courts of appeals as the forums for judicial review of administrative agency action, there has been occasional reliance on specialized courts of review. ${ }^{58}$

\section{A. Established Specialized Courts}

One of the first such courts was the Court of Claims created in 1855 to decide monetary claims against the United States that previously had to be decided by Congress. $^{59}$ It later evolved into an appellate forum, reviewing the decisions of Commissioners it appointed regarding contract and other non-tort claims under the Tucker Act. In 1982, however, Congress gave its appellate functions to the new Court of Appeals for the Federal Circuit and created a new Article I trial court, the United States Claims Court. ${ }^{60}$ In 1992, the trial court's name was changed to the United States Court of

\footnotetext{
${ }^{57}$ See MASHAW ET AL. supra note 15, at 146-50. A more recent study has come down on the side of an Article I court structure. See Levy, supra note 10, at 461.

${ }^{58}$ For good overviews see, e.g., Harold H. Bruff, Specialized Courts in Administrative Law, 43 ADMIN. L. REV. 329 (1991); Rochelle Cooper Dreyfuss, Specialized Adjudication, 1990 B.Y.U. L. REV. 377; and Richard L. Revesz, Specialized Courts and the Administrative Lawmaking System, 138 U. PA. L. REV. 1111 (1990).

${ }^{59}$ The Supreme Court held it to be an Article I court in Gordon v. United States, 69 U.S. (2 Wall.) 561 (1964) and again in Williams v. United States, 289 U.S. 553 (1933). After Congress declared it to be an Article III court, the Supreme Court so held in Glidden v. Zdanok, 370 U.S. 530 (1962).

${ }^{60}$ See Bruff, supra, note 55 at 332-333. The judges of the Court of Federal Claims can be removed only for cause and with the concurrence of a majority of the judges of the Federal Circuit. See FED. CourTS STUDY COMM., WORKING PAPERS AND SUBCOMMITTEE REPORTS (July 1, 1990) (Vol. I) 170 n. 27.
} 
Federal Claims. ${ }^{61}$ It now has sixteen judges who serve fifteen-year terms. Its headquarters is in Washington, DC, but cases are heard in other locations convenient to the parties. ${ }^{62}$

Another such court was the Court of Customs Appeals, created in 1909 to hear appeals from the Board of General Appraisers which had been aeated in 1890 to adjudicate various customs disputes. The Board's name was changed to the United States Customs Court in 1926 and it became an Article III court in 1956. Meanwhile the Court of Customs Appeals became the Court of Customs and Patent Appeals ("CCPA") in 1929 when Congress added jurisdiction over appeals from the Commissioner of Patents which had previously been heard by the D.C. Circuit. In 1980, the CCPA was also given appellate authority over a new Article III court, the Court of International Trade, which subsumed the Customs Court and also was given jurisdiction over international trade cases that theretofore had been heard in the district courts. ${ }^{63}$

Finally in 1982, the Court of Appeals for the Federal Circuit ("CAFC") was created as the only non-geographic circuit court of appeals. ${ }^{64}$ It was created as an Article III court and given jurisdiction of the former CCPA, (customs, trade and patent cases) plus a potpourri of other appeals: appeals from the Claims Court, the International Trade Commission, the Merit Systems Protection Board, Boards of Contract Appeals, and a few

\footnotetext{
${ }^{61}$ See Federal Court Administration Act of 1992, Pub. L. No. 102-572, 106 Stat. 4506 (1992).

${ }^{62}$ See http://www.uscourts.gov/understanding_courts/89921.htm.

${ }^{63}$ See Fed. COURTS STUdy COMM., WORKING PAPERS AND SUBCOMMITTEE REPORTS (July 1, 1990) (Vol. I) $170-74,189-92$.

${ }^{64}$ The Court of Appeals for the District of Columbia Circuit ("DC Circuit") also has some specialized jurisdiction, due to exclusive venue provisions in certain regulatory areas. Its members may also be appointed without regard to residence. However, in general it acts like an ordinary regional court of appeals.
} 
other agency and district court decisions. ${ }^{65}$ In 1988, the CAFC also acquired jurisdiction of appeals involving legal questions from the newly created Court of Veterans Appeals (now named the Court of Appeals for Veterans Claims). The CAFC sits in Washington, DC, but may convene anywhere in the United States.

The other specialized courts that now exist ${ }^{66}$ are Article I courts. They are labeled Article I rather than Article III principally because their judges do not have life tenure under the Constitution. ${ }^{67}$ The Tax Court began in 1924 as the Board of Tax Appeals - a quasi independent entity of the Treasury Department. In 1969, it was reshaped into an Article I Tax Court. ${ }^{68}$ It currently has nineteen judges who serve fifteen-year terms plus seventeen special trial judges appointed by the Chief Judge. ${ }^{69}$ Although the district courts continue to hear some cases where taxpayers have paid the tax and then seek a refund, the Tax Court hears 90 percent of the appeals from the Internal Revenue Service. Its headquarters is in Washington, DC, but it hears cases in approximately eighty cities. Appeals from the Tax Court go to the regional circuit courts. ${ }^{70}$

The Court of Veterans Appeals (referred in Part I and described more fully in Part VII(A)(3)) was created in 1988 to provide, for the first time, judicial review in veterans' benefits cases decided by the Veterans Administration (now the Department of Veterans

\footnotetext{
${ }^{65}$ It was created based on the report of the Hruska Commission, which also recommended a National Court of Appeals. See Fed. COURTS StUdy COMM., WORKING PAPERS AND SubCOMMITTEE REPORTS (July 1, 1990) (Vol. I) 192.

${ }^{66}$ From 1910-1913, a short-lived Commerce Court was created to review decisions of the Interstate Commerce Commission. Its narrow jurisdiction and charges of capture led to its early dissolution. See id. at $174-76$;

${ }^{67}$ There are some independent boards and commissions that function in a fashion similar to Article I courts (such as the Occupational Safety and Health Review Commission and the Federal Mine Safety and Health Review Commission), but they will not be discussed here.

${ }^{68}$ See Claudia MacLachlan, The Tax Bench: A Code Apart, 16 NAT'L L. J. No. 4, p.1 (Sept. 27, 1993).

${ }^{69}$ See http://www.ustaxcourt.gov/ustcweb.htm.
} 
Affairs). ${ }^{71}$ The court (renamed the Court of Appeals for Veterans Claims in $1998^{72}$ ) hears decisions made by the Department's presidentially appointed, administrative Board of Veterans Appeals; further appeals, on matters of law only, may be taken to the CAFC. The operation of this court is more fully described in Part VII of this Report.

The Article I U.S. Court of Military Appeals was created by Congress in 1950 when Congress also enacted the Uniform Code of Military Justice, which established a military judicial system. ${ }^{73}$ This system was designed to give members of the military services, who are accused of crimes, rights paralleling those of civilians. In 1994, the name of the court was changed to the U.S. Court of Appeals for the Armed Forces. The court's jurisdiction encompasses questions of law arising from trials by court-martial in the United States Army, Navy, Air Force, Marine Corps, and Coast Guard in cases where a death sentence is imposed, where a case is certified for review by the Judge Advocate General of the relevant service, or where an accused, facing a severe sentence, petitions and shows good cause for further review. The five judges of the U.S. Court of Appeals for the Armed Forces are civilians appointed for fifteen-year terms by the President with the advice and consent of the Senate. The chief judge serves for five years and is succeeded by the next senior judge on the court. The court is located in Washington, D.C.

In addition to Article I Courts, there are two groups of Article I judges attached to the U.S. District Courts: magistrate judges and bankruptcy judges.

\footnotetext{
${ }^{70}$ Taxpayers may also seek refunds in the Claims Court—but appeals from that court go to the CAFC.

${ }^{71}$ Veterans' Judicial Review Act, Pub. L. No. 100-687, §301, 102 Stat. 4105, 4113 (1988).

${ }^{72}$ Its name was changed effective March 1, 1999, by the Veterans' Programs Enhancement Act of 1998, Pub. L. No. 105-368.

${ }^{73}$ The information about the court is from its website, http://www.armfor.uscourts.gov.
} 
Magistrate judges are appointed by majority vote of the active district judges of the court to exercise jurisdiction over matters assigned by statute as well as those delegated by the district judges. ${ }^{74}$ The number of magistrate judge positions is determined by the Judicial Conference of the United States, based on recommendations of the respective district courts, the judicial councils of the circuits, and the Director of the Administrative Office of the U.S. Courts. A full-time magistrate judge serves a term of eight years. Duties assigned to magistrate judges by district court judges may vary considerably from court to court, and as we have seen, they play a central role in the disposition of SSA disability cases. At present, there are 471 full-time and 59 part-time magistrate judges. ${ }^{75}$

Bankruptcy judges are appointed by the majority of judges of each U.S. circuit to exercise jurisdiction over bankruptcy matters. The number of bankruptcy judges is determined by Congress based on recommendations of the Judicial Conference of the United States. Bankruptcy judges are appointed for fourteen-year terms. As of the end of 2001, there were 324 authorized bankruptcy judgeship positions. ${ }^{76}$

Decisions of both magistrate judges and bankruptcy judges are subject to review by the supervising district court judge, though an interesting aspect of the bankruptcy judge structure is that a statute provides that the circuit court may create a "bankruptcy appellate panel service" composed of bankruptcy judges of the districts in the circuit to

\footnotetext{
${ }^{74}$ See generally Leslie G. Foschio, A History of the Development of the Office of United States Commissioner and Magistrate Judge System, 1999 FED. CTS. L. REV. 4, available at http://www.fclr.org/1999fedctslrev4.htm.

${ }^{75}$ See website for the Federal Magistrate Judges Association, available at http://www.fedjudge.org.

${ }^{76}$ See "Cars, Planes-and Video Cameras-Take Bankruptcy Judges to Outlying Locations," available at http://www.uscourts.gov/Press_Releases/bkjtravel.html.
} 
hear appeals from individual bankruptcy judge decisions. ${ }^{77}$ Appeals heard under this process are heard by a panel of three members of the bankruptcy appellate panel service, except that a member of such service may not hear an appeal originating in the district for which such member is appointed or designated. ${ }^{78}$ In addition, such a procedure must be authorized by a majority of the district court judges of the district. ${ }^{79}$

Bankruptcy Appellate Panels provide an example of a two-tier process, using the same pool of adjudicators. The Association of [SSA] ALJs has proposed that the SSA ALJ corps be reconstituted into a two tier stage, modeled on the Bankruptcy Appellate Panels, and that this stage be the final agency decision. ${ }^{80}$ The ALJs' report argues that since 1.3 million cases are filed with the first level bankruptcy courts, and that 500,000 cases are filed with SSA ALJs, lessons should be drawn from the bankruptcy system. The report also argues that bankruptcy practitioners believe that panel decisions produce better products, ${ }^{81}$ that in circuits with such panels, there are far fewer appeals to the court of appeals, ${ }^{82}$ that bankruptcy panels produce decisions in a very short time, ${ }^{83}$ and that the potential for service on such panels improves judicial morale. ${ }^{84}$ While the SSA ALJ study's conclusions on this point have not been reviewed thoroughly, this is a proposal

\footnotetext{
7728 U.S.C. $\$ 158(\mathrm{~b})(1)$. See Tisha Morris, Establishment of Bankruptcy Panels Under the Bankruptcy Reform Act of 1994: Historical Background and Sixth Circuit Analysis, 26 U. MEMPHIS L. REV. 1501 (1996) and Thomas E. Carlson, The Case for Bankruptcy Appeals Panels, 1990 B.Y.U. L. REV. 545,575 (finding the panels to be "an unqualified success).

7828 U.S.C $\$ 158(\mathrm{~b})(1)(5)$.

7928 U.S.C $\$ 158(b)(1)(6)$.

${ }^{80}$ REPORT ON NEW INDEPENDENT REGULATORY AGENCY, supra note 10, at 40-43.

81 Id. at 42, citing Thomas A. Wiseman, Jr., The Case Against Bankruptcy Appellate Panels, 4 GEO. MASON. L. REV. 1, 7 (1995).

${ }^{82}$ Id. at 42, citing Morris, supra note 74, at 1517-19.

${ }^{83}$ Id. at 42, citing Morris, supra note 74, at 1530 (giving the average disposition time of 75 days).

${ }^{84}$ Id. at 43, citing Morris, supra note 74, at 1509.
} 
worth considering given the current extensive delays at, and limited policy review by, the Appeals Council.

\title{
B. Other Recent Proposals for Specialized Courts Relating to Social Security ${ }^{85}$
}

In 1971, the "Ash Council" ${ }^{86}$ recommended the creation of a specialized appellate

court to hear appeals from restructured transportation, power, and securities agencies.

\begin{abstract}
${ }^{85}$ It should be noted that there have also been several specialized courts made up of sitting judges. These include two "emergency" courts. The Emergency Court of Appeals ("ECA") was created in 1942 to handle appeals from the wartime price administrators. The court was staffed by sitting federal judges from throughout the nation appointed by the Chief Justice. Its constitutionality was upheld by the Supreme Court in 1944 in Yakus v. United States, 321 U.S. 414, 437-38. It stayed in existence until 1961 to handle appeals from various post-war and Korean War related programs. See FED. COURTS STUDY COMM., WORKING PAPERS AND SUBCOMMITTEE REPORTS (July 1, 1990) (Vol. I) 176-81. In 1971, economic conditions led to similar wage and price controls and the Temporary Emergency Court of Appeals was created. It is also composed of sitting judges and its size has varied over the years (e.g., 20 in 1982 and 12 in 1989). See id. at 182. A few years later it was given jurisdiction over reviews of energy program disputes. The court was dissolved in 1993 at the request of the Judicial Conference. Another temporary highly specialized court consisting of sitting judges was created in 1973-the Special Court created by the Regional Rail Reorganization Act of 1973. The court was set up to adjudicate consolidated claims stemming from the railroad reorganization that led to the creation of Conrail. See id. 185-86.
\end{abstract}

In 1978 the Foreign Intelligence Surveillance Act created a special court made up of seven sitting district court judges from different circuits, appointed by the Chief Justice to hear applications for and to grant orders approving electronic surveillance anywhere within the United States. There is also a three-judge appeals court made up of sitting district or appeals judges to which denials of wiretap orders may be appealed, with certiorari review (under seal) to the Supreme Court. See 50 U.S.C. § 1803. According to one critic of the court, as of November 2000, it received 7,539 applications to authorize electronic surveillance within the United States from the Justice Department on behalf of the Federal Bureau of Investigation and the National Security Agency. In the name of national security, the court has approved all but one of these requests. Each of these decisions was reached in secret, with no published orders, opinions, or public record. See Philip Colangelo, The Secret FISA Court: Rubber Stamping Our Rights, COVERT ACTION Q. (Nov. 27, 2000), available at http://www.rense.com/general5/fisacourt.htm. The two courts are known as the Foreign Intelligence Surveillance Courts. See FED. CourTs STUdy Comm., WORKING PAPERS AND SUBCOMMITTEE REPORTS (July 1, 1990) (Vol. I) 187-89.

In 1996 an Alien Terrorist Removal Court was created pursuant to the Antiterrorism and Effective Death Penalty Act of 1996. Pub. L. No. 104-132. This court, which is made up of five sitting district court judges from different circuits, appointed by the Chief Justice, conducts proceedings based on applications brought by the Attorney General to determine whether an alien should be removed from the United States on grounds of being a terrorist.

Also, the 1978 Ethics in Government Act, Pub. L. No. 95-521 § 602 (codified at 28 U.S.C. § 49) (establishing special division of the DC Circuit to appoint special prosecutor; amended to substitute term "independent counsel" in 1983) created a special Court of Appeals "Division to Appoint Independent Counsels." 28 U.S.C $\$ 49$. The statute specified that one of the three shall be a member of the DC Circuit and that not more than one judge or justice or senior or retired judge or justice may be named to such division from a particular court. See id. Under this statute, three judges or justices were assigned for twoyear periods to a division of the United States Court of Appeals for the DC Circuit for the purpose of appointing independent counsels. This division ceased to exist with the non-renewal of the Independent Counsel statute. 
The Administrative Conference of the U.S. issued a statement in 1971 opposing this particular proposal on a number of grounds that might be relevant here, though SSA decisions are not the same sort of regulatory decisions. ${ }^{87}$ Such concerns include the benefits of having generalist judges provide scrutiny of agency action as to its fairness and consistency with statutory norms, the danger that a narrowly specialized reviewing court might become or appear to become identified with the agency, and the risk that the appointments to such a court would pose a problem of adequate public oversight. ${ }^{88}$

In 1977, the tenor of the debate about the need for specialized courts changed with the publication of "The Needs of the Federal Courts" by the Department of Justice Committee on Revision of the Federal Judicial System, chaired by Robert Bork. The "Bork Report" identified a crisis of case volume in the district courts and urged the creation of new non-Article III tribunals in the district courts to handle certain types of cases characterized by relatively unsophisticated, repetitious factual issues that rarely give rise to important legal questions. Among these were social security cases. ${ }^{89}$

The ABA House of Delegates in August 1982 opposed creation of an Article I Social Security Court for the reasons described in Part V of this Report. This resolution was sponsored by the ABA's Commission on Legal Problems of the Elderly and

\footnotetext{
86 THE PRESIDENT'S ADVISORY COUNCIL ON EXEC. ORG., A NEW REGULATORY FRAMEWORK: REPORT ON SElECTED REGUlAtory AgENCIES (1971) (chaired by businessman Roy L. Ash). See Nathaniel L. Nathanson, The Administrative Court Proposal, 57 VA. L. REV. 996 (1971).

${ }^{87}$ ACUS, Statement 1, Views of the Administrative Conference on the "Report on Selected Independent Regulatory Agencies" of the President's Advisory Council on Executive Organization, 38 Fed. Reg. 19,974 (July 23, 1973).

${ }^{88}$ See also the ACUS-sponsored article, David Currie \& Frank Goodman, Judicial Review of Federal Administrative Action: Quest for the Optimum Forum, 75 COLUM. L. REV. 1, $62-88$ (1975) (critiquing proposals for specialized courts).

${ }^{89}$ After listing examples of these types of cases, the Committee stated, "These matters have great individual and social significance but the questions they raise could be handled as effectively and justly by trained
} 
Commission on the Mentally Disabled. ${ }^{90}$ In 1989, the Sloan Foundation commissioned a review of the SSA appeals process that, among other things, strongly recommended the creation of a Social Security Court. ${ }^{91}$ The report recommended that the new court be an Article III court, and that appeals from the court go to the Court of Appeals for the Federal Circuit.

In 1990, another thorough study of the SSA appeals process, by Professor Richard Levy, recommended the creation of an Article I "Court of Disability Appeals" (created by expanding the jurisdiction of the then-named Court of Veterans Appeals) which would substitute for the review responsibilities of both the Appeals Council (which would be assigned policymaking functions) and the district courts. Appeals from the disability court would mirror those from the veterans court, in that they would be limited to legal questions. The administrative law judge corps would be made independent of the SSA as well. Under Professor Levy's proposal, the SSA would be entitled to seek review in the disability court. ${ }^{92}$

Also in that same year, a special Federal Courts Study Committee, undertook a comprehensive study of the entire federal judiciary. The Committee, consisting of a select panel of fifteen federal judges, Members of Congress and distinguished lawyers, formally recommended that:

administrative judges as by Article III judges burdened with the pressing business of a general criminal and civil jurisdiction." Report at page 9.

${ }^{90}$ Proposed resolution on file with authors.

91 See, e.g., Frederick B. ARner, AlFred B. SloAn Found., A Model DiSABility STRUCTURE FOR THE SOCIAL SECURITY ADMINISTRATION 110 (Sept. 1989) ("Of all the suggestions for change in the various levels of adjudication, I believe recommending the creation of a Social Security Court is the most clear cut and easiest to make.")

92 See Levy, supra note 10 at 512-37. 
Congress should create a new structure for adjudicating disability claims under the Social Security Act: hearings before administrative law judges with adequate institutional independence, whose decisions could be appealed to a new Article I Court of Disability Claims, with review in the courts of appeal limited to constitutional claims and to pure issues of law. ${ }^{93}$

This report concluded that: "[t]he principal issues in most Social Security disability cases are factual and technical. Thus it is best to concentrate adjudicative resources at the administrative level and create a new appellate court that will attract competent specialists in disability law."94

It also stated its belief that the new court "will provide a more thorough and expert examination of facts than federal district court can provide, given the other demands on their time." 95 It also suggested that Congress may wish to consider expanding the jurisdiction of such a court to include claims now handled by the Court of Appeals for Veterans Claims_-which it said might provide a good model for the proposed new Court of Disability Appeals. It concluded that " $[\mathrm{t}]$ he enhanced authority and prestige of such a court would attract the ablest specialists in the field of disability law, and the broader the court's jurisdiction, the more it will alleviate the Article III judiciary's disability caseload." ${ }^{96}$ As for the Appeals Council, which would lose its appellate adjudicative responsibilities under the proposal, the Committee suggested it be reconstituted "as an agency to promulgate the regulations that guide the adjudication of Social Security disability cases" in the manner that the Occupational Safety and Health

\footnotetext{
${ }^{93}$ REP. OF THE FED. COURTS STUDY COMM. 55 (Apr. 2, 1990).

${ }^{94} I d$. at 56.

${ }^{95} I d$.

${ }^{96} I d$. at 57.
} 
Administration does for the independent Occupational Safety and Health Review Commission (OSHRC). ${ }^{97}$

Most recently the Commission on Structural Alternatives for the Federal Courts of Appeals, chaired by Justice Byron White in December 1998 issued a report that said Congress should seriously consider proposals for an Article I Social Security Court, perhaps with exclusive appellate jurisdiction in the CAFC on the same basis as for veterans' appeals—review limited to constitutional and statutory questions. ${ }^{98}$

\section{Proponents' Arguments for a Social Security Court}

As discussed above, proponents have cited relief for the Article III district courts as well as benefits for the social security adjudication process itself. The Bork Report pointed to the dramatic increase in federal district court filings of social security cases and argued that this has significantly added to the overall backlog in district courts (and presumably in the courts of appeals). Proponents also argue that disability filings have created painful delays in resolution of claims by district courts since these cases must compete with all the other civil and criminal business in the federal courts.

Another alleged problem is that of non-uniformity, which is a function of the number of district court and court of appeals judges passing on these cases. Nonuniformity, in turn, leads to difficulties in administration of the program at the agency level. A specialized court could create uniform substantive norms that would be more easily communicated throughout the SSA system.

\footnotetext{
97 This recommendation was not unanimous. Senator Charles Grassley (R-IA) dissented and three other members issued a counter proposal which would substitute a Benefits Review Board of the Appeals Council, maintain district court review, but limit court of appeals review to questions of law. Id. at 58-59.

98 COMM'N ON STRUCTURAL Alternatives FOR THE FED. COURTS OF APPEALS, FinAL REPORT, submitted to the President and the Congress pursuant to Pub. L. No. 105-119, (Dec. 18, 1998) p.74.
} 
Finally, proponents argue that the vast majority of these cases, involve only factual issues. It is inefficient to require a generalist Article III judge to attempt to evaluate medical and other evidence to determine if the administrative decision is supported by substantial evidence. It is far better, proponents argue, to have decisionmaking in an administrative forum that would obtain experience and expertise in the evaluation of the disability program. ${ }^{99}$

\section{$\underline{\text { A. Caseload Concerns }}$}

The 1990 Federal Courts Study Committee stressed the effect of SSA disability claims appeals on the courts. The Committee's working papers mentioned that such appeals constituted a significant portion of the district courts' workload—ranging from 5.3 percent to 11 percent from 1983 to 1988 , and 3.0 percent to 4.2 percent of the court of appeals caseload. ${ }^{100}$ Equally persuasive to the Committee was that complaints received from federal judges "were virtually unanimous in mentioning Social Security cases. Judges apparently find these cases burdensome, but feel that their efforts contribute little to improving administration in this area."101

\footnotetext{
${ }^{99}$ See, e.g., ARNER, supra note 89 at 110-125 (arguing for the creation of an Article III Social Security Court).

${ }^{100}$ See Fed. COURTS StUdy COMM., WORKING PAPERS AND SUbCOMMITTEE REPORTS (July 1, 1990) (Vol. I) 285. The court of appeals judges were also surveyed on their attitude toward specialized courts. Only 52 opined that additional specialized courts would be desirable as opposed to 80 who said it would be undesirable. However, when respondents were asked "if you favor more specialized courts, what areas would be most appropriate (check all that apply)?" the responses were Social Security (64), Tax (45), Administrative (30) and Other (16). Id. (Vol. II) ("Survey of Circuit Judges") (unpaginated). No similar question was included in the Survey of District Judges.

${ }^{101} I d$. at 285-86.
} 
It seems clear that, as Professor Levy concluded, "the substantial judicial resources allocated to disability determinations are not used in a cost-effective manner." ${ }^{102}$ He points out:

Instrumentally, the added layers of judicial review might correct some of the random good faith errors that inevitably slip through the complex disability determination process. On the other hand, judicial review is illsuited to perform this corrective function. Judges have no particular expertise concerning the technical medical and vocational judgments necessary to determine disability. Even the legal questions involved in disability determinations are usually highly technical issues on which courts normally defer to agency expertise. ${ }^{103}$

Moreover, "[g]iven the recurring backlogs and delays in the administrative disability determination process, securing judicial relief from an erroneous benefit decision is a time consuming process at best, and many meritorious appeals may be lost to attrition." 104

Chief Judge Pierce Lively of the Sixth Circuit in a 1986 interview summarized this view of the social security appeals process from the perspective of the federal bench:

When you examine carefully what is involved in the Social Security appeal, it becomes clear, to me at least, that we are not using our judicial resources very wisely.... There is no new hearing after the administrative law judge's action. The magistrate makes a recommendation, and the district judge is required to review that same administrative record de novo before either accepting or rejecting the magistrate's recommendations. This is all done on cross-motions for summary judgment. If the answer is still "no benefits," the claimant may appeal to the court of appeals for his or her circuit. Three judges are then required to read the administrative record, and in some cases hear oral argument. In most cases, the only question from the time the proceedings end in the Social Security Administration is whether the decision is supported by substantial evidence. All of the judges are merely reviewing factual

\footnotetext{
${ }^{102}$ Levy, supra note 10 , at 508.

${ }^{103} I d$. (footnotes omitted).

${ }^{104} I d$.
} 
matters, and a very large portion of each record consists of medical records.

It seems to me that a special court could quickly acquire some expertise in this field. I don't denigrate the importance of Social Security cases to the litigants; like all cases they are the most impotant [sic] thing in the world to the parties involved. But I do think the claimants would get much faster answers in a special court than they now do, being required to take their turn on the crowded district court and courts of appeals dockets. ${ }^{105}$

Today, there are even more reasons to believe the disability caseload will continue to increase. As noted at the outset, the aging of the baby boom generation will likely produce an upsurge of applications and disputes. ${ }^{106}$ Moreover, SSA has recently resumed its program of continuing disability reviews of existing beneficiaries, after Congress authorized $\$ 4.3$ billion for this purpose for FY 1996 to FY 2002. ${ }^{107}$ CDRs tripled from about 600,000 in 1997 to 1.8 million in 2000. ${ }^{108}$ Because CDRs can lead to a termination of benefits in some cases, an upsurge in hearing requests, and, eventually, a higher tide of appeals to the federal courts might be expected, as happened with a similar policy in the 1980s. ${ }^{109}$ On the other hand, the impact of CDRs on the judicial caseload

\footnotetext{
105 Interview with Chief Judge Pierce Lively, 18 THIRD BRANCH 1, 5 (June 1986).

106 See text at note 5, supra.

107 SSAB, DISABILITY DECISION MAKING, supra note 26, at 28.

108 See id.

${ }^{109}$ One critic of Social Security Court proposals in the 1980s stated that:
}

In the 1983 fiscal year, the [SSA] Office of Hearings and Appeals received over 134,000 requests for hearings in Continuing Disability Review (CDR) cases, accounting for 36.4 percent of the requests received. The SSA's own reinstatement statistics bear witness to an unconscionably high rate of wrongful terminations during the period. By March 1984, federal officials were reporting that over 470,000 people had been removed from the disability rolls in the preceding three years, 160,000 had already been reinstated after appeals, and another 120,000 cases were pending. Suddenly, the administrative system had to cope with the influx of hundreds of thousands of terminated disability recipients appealing their cases.

Robert E. Rains, A Specialized Court for Social Security? A Critique of Recent Proposals, 15 Fla. St. U. L. Rev. 1, 7-8 (1987) (footnotes omitted). It is no coincidence that filings in federal district court peaked at 27,500 in FY 1984, then dropped to 20,000 in FY 1985, and to just over 10,000 in FY 1986, after the CDR program was terminated. 
will be a function of the number of actual terminations that result from the review process, and it is doubtful that the SSA would permit terminations to reach the levels that occurred in the 1980s. ${ }^{110}$

But whatever the cause, it is clear that district court filings in social security cases are on the upswing again-13,059 in FY $1999^{111}$ and over 15,000 in FY 2000. ${ }^{12}$ The number of new disability cases filed in the federal courts nearly tripled between 1990 and $2000 . .^{113}$

\section{B. Uniformity Concerns}

Proponents of a Social Security Court also focus on the problem of inconsistent application of the law, both vertically within the different levels of the disability adjudication system, and horizontally in different regions and judicial districts. The concerns are voiced, for example by the National Association of Disability Examiners (“NADE"), a professional organization, many of whose members are employed in the state Disability Determination Service ("DDS") offices and are directly involved in processing claims for Social Security disability benefits. In Congressional testimony, the

NADE President summarized her concerns about the lack of uniformity:

Disability decisions are not made in a nationally uniform and consistent manner. While to some extent this has always been true, it has become increasingly more pronounced in recent years. For several reasons, we are concerned that this trend will continue. New policies developed by SSA, both in response to, and independent of, court decisions and other litigation, have required that increasingly more weight be given to the subjective complaints of disability applicants. Similar impairments will

\footnotetext{
${ }^{110}$ See discussion at note 10 and accompanying text concerning the reasons why SSA's independent status was meant to prevent a return to the 1980 s CDR situation.

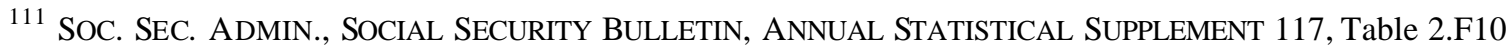
(2000).

${ }^{112}$ SSAB, DiSABILITY DECISION MAKING, supra note 26, at 84 .

${ }^{113} I d$.
} 
affect different individuals in different ways. Assessing these subjective complaints necessarily has added to the growing belief that there is a general lack of consistency in what the public believes should be a uniform national program.

Social Security lacks a clear and uniform quality review process that would provide consistent, meaningful feedback to all decision-makers. Quality assurance reviews and the "adjudicative climate" under which claims are reviewed, are inconsistent and reflective of-and convoluted by -politics and/or litigation. Regulations are frequently promulgated and implemented before operating procedures, instructions and other tools have been developed. Decisions made by Administrative Law Judges are driven by court decisions while decisions made in the DDSs are controlled by program directives issued by SSA. . .

$* * *$

In order to increase the consistency and uniformity of disability decisions, the Social Security Administration must become truly "one SSA". . . . ${ }^{114}$ NADE has made numerous recommendations concerning SSA administration, but

the organization also comes down squarely in favor of a new court:

NADE has long supported the establishment of a Social Security Court. The development of - and decision on - an individual's claim should not be dependent upon their residence or judicial jurisdiction. The everincreasing complexity of disability claims, and the growth of medical technology, makes the need for a specialized court, with expertise in these matters, a necessity. ${ }^{115}$

In addition, Frederick Arner has emphasized that uniformity is a basis for preferring a Social Security Court, although be ultimately favored such a court under Article III rather than Article I. ${ }^{116}$

\section{$\underline{\text { V. Opponents' Arguments Against a Social Security Court }}$}

Led by claimant representatives and senior citizen organizations, opponents counter with various arguments. They claim that the impact of social security cases on

\footnotetext{
${ }^{114}$ Statement of Sue Heflin, President, National Association of Disability Examiners, Testimony Before the Subcommittee on Social Security of the House Committee on Ways and Means Hearing on Social Security Disability Program's Challenges and Opportunities 107th Cong. (June 28, 2001) available at http://waysandmeans.house.gov/socsec/107cong/6-28-01/6-28hefl.htm

${ }^{115} I d$.

116 See ARNER, supra note 89, at 110-14 (citing other sources for uniformity of decisionmaking).
} 
the federal court backlog is overstated. They argue that the Administrative Office of the U.S. Courts weights these cases at approximately one-fourth the level of an average case and that many are, for practical purposes, decided by magistrate judges. They also claim that SSA's policies of nonacquiescence, dilatory requests for remands, and other policies are responsible for the high caseloads and that it would be improper to "reward" SSA for these activities by creating a Social Security Court ("SSC"). This assumes that an SSC would be more partial to SSA than current district courts, which is hard to predict. But it may not be a bad assumption given that district courts have been remanding or reversing SSA denials in over 50 percent of the appeals, ${ }^{117}$ notwithstanding that the scope of review is not de novo but is based on the supposedly deferential "substantial evidence" test. The opponents have argued that it is this reversal rate that is the real motivation for moving cases out of the district courts and that the nonuniformity is not that great among districts or circuits. ${ }^{118}$ On the other hand, independent Article I courts may be no less demanding. The Court of Appeals for Veterans Claims produces at least partially favorable results for claimants in 46 percent of its cases, ${ }^{119}$ and this is after a administrative process that is supposed to resolve all reasonable doubts in favor of the veteran.

A related argument is that the SSC will become a rubber stamp for SSA. The concern is that such a court will be faced with low staffing, high caseloads, and an inevitable monotony or redundancy in the cases, and, thus, will become jaded and

\footnotetext{
${ }^{117}$ While district courts reverse SSA outright in relatively few cases, the remand rate has grown from 37 percent in 1996 to 48 percent in 2000. See SSAB, DISABILITY DECISION MAKING, supra note 26, at 85; see also notes 44-46 and accompanying text, supra.

${ }^{118}$ It is evident that there is significant variation among district and circuits. See infra, Appendix B (e.g. District of West Virginia 3.6 percent reversals; Northern District of California 1 percent reversals; and Eastern District of New York 27.8 percent reversals, etc.).

${ }^{119}$ See text at note 186 , infra.
} 
eventually act as the SSA Appeals Council purportedly does now-routinely dismissing appeals.

The rest of opponents' arguments boil down to the benefits of generalist judges, even assuming the widespread use of magistrate judges to decide most of these cases now; the need to modify the administrative procedures of SSA before tinkering with judicial review; the unfairness of giving social security claimants "second class justice;" and specific deficiencies of the SSC proposals, such as the lessened independence of Article I judges, the lack of availability of class-action procedures or injunctive relief, and the cost of traveling to the hearings.

Opponents also counter the uniformity argument, not by questioning its goals, but by arguing that the nonuniformity is overstated. Professor Rains argued that the Congress and the Supreme Court can redress these problems. ${ }^{120}$ Moreover he argues that the problem has largely been caused by the SSA.

Nonuniformity exists largely between the SSA and the circuits rather than among the circuits themselves. The reality is that SSA objects to relatively uniform adverse decisions largely brought about in recent years by the SSA's obstinance, or . . . its lawlessness.

The cry of nonuniformity is a smokescreen. One can only suspect that the administration favors the establishment of the Social Security Court in the hope that such a court would abandon settled precedent and create new precedent more favorable to the Social Security Administration. ${ }^{121}$

As can be seen from the above quotation, there is also a political subcurrent to all this, reflecting the hopes and fears surrounding the appointment process for the new court. This reflects the concerns that a President will suddenly have the opportunity to

\footnotetext{
${ }^{120}$ Rains, supra note 106 , at 23-24.

${ }^{121} I d$. at 24. One wonders whether this fear couldn't be assuaged by legislative direction to a new Article I court to follow established precedent unless extraordinary reasons for departing from it are given.
} 
appoint the entire initial membership of the new court. ${ }^{122}$ A more subtle concern transcends concerns relating to a particular President. It relates to agency "capture"that the nomination process might be influenced by groups (or DOJ itself) which also would have similar influence in the selection of the SSA Commissioner and therefore the SSA Court might be staffed with judges who share the same policy views as the SSA Commissioner, thus making it more pro-agency.

As Professor Revesz has written:

For example, under a scheme of specialized courts, the Justice Department can strive for a perfect identity between the views of a nominee to a hypothetical Court of Social Security Appeals and those of the Social Security Administration. If, in contrast, the responsibility for judicial review of this agency's decisions remains in the generalist courts, the Justice Department would have to consider whether a nominee that is desirable from the perspective of the Social Security Administration is also desirable from the standpoint of, say, the Department's own interest in the enforcement of federal criminal law. It is unlikely that any individual would be ideal from all perspectives.

Of course, the influence of the Justice Department is likely to be the strongest, and the biasing effect most pronounced, where the Department faces a weak private bar, as is true, for example, in Social Security cases. There, the bar is unlikely to provide strong counter-weight to the Department's interest in securing sympathetic judges on the specialized court. In contrast, where the Department faces a strong private bar, the effect will be considerably mitigated, and may in fact pull in the opposite direction as a result of the group's capture of the nomination process. ${ }^{123}$

Professor Revesz has also acknowledged the concern that the judges on the SSC

would have an overly narrow perspective:

[S]pecialized judges tend to come from relatively narrow segments of the profession and are therefore less likely than generalist judges to have been

\footnotetext{
122 Although, presumably the Congress could add a political party affiliation requirement as it has done for multi-member administrative agencies. See Marshall J. Breger \& Gary J. Edles, Established by Practice, The Theory and Operation of Independent Federal Agencies, 52 ADMIN. L. REV. 1099, 1137 (2000).

${ }^{123}$ Revesz, supra note 55, at 1152.
} 
exposed to a wide range of legal issues. Moreover, because they do not adjudicate cases outside their area of specialization, they are also unlikely to broaden their outlook once on the bench. Thus, in general, specialized judges will be less skilled than their generalist counterparts at applying concepts from other areas of law, even if the relevant reference points were brought to their attention.

This problem may well be exacerbated by the bar that can be expected to form around a specialized court. Experience with specialized courts suggests that such courts will develop idiosyncratic procedures. When a court's procedures are not common to those of other courts, the high cost of becoming familiar with such procedures provides serious disincentives for lawyers to practice before the specialized court only occasionally. Thus, lawyers who practice before specialized courts will be less likely than those who practice before generalist courts to work daily with a broad cross-section of federal law. ${ }^{124}$

But he qualified his opposition to specialized courts where decisions of

such courts are reviewable by the generalist courts of appeals.

However, the negative effects of specialized courts identified in this Article do not apply if the courts are subject to review, as of right, by the generalist, regional circuits. Then, the specialized court would be overseen by a forum that does not exhibit the systemic biases that are likely to be found in specialized courts; that is functionally well suited and capable of drawing insights from other areas of law, thereby promoting the coherence of federal law; and that is capable of engaging in dialogue designed to improve the quality of legal rules.

Thus, the negative effects discussed in this Article do not apply to . . the Tax Court, OSHRC, and [the Federal Mine Safety and Health Review Commission] (FMSHRC)]. Similarly, the negative effects would not apply to the proposed Social Security Court, as long as its decisions were subject to review as of right in the regional circuits. ${ }^{125}$

${ }^{124} I d$. at 1163-64 (footnote omitted).

${ }^{125} I d$. at 1165-66 (footnotes omitted). On the other hand, with respect to the proposals for a Social Security Court, he has cautioned that one often overlooked benefit is that the courts have often used SSA courts to propound important legal doctrines:

Clearly, this is not the place to analyze competing claims, but it is relevant to recall that such fundamental issues as the scope of class actions or of the injunctive power of the federal courts have been resolved in the context of Social Security cases, which some believe to be relatively routine and therefore unworthy of the generalist courts.

Id. at 1170 (footnotes omitted). 


\section{Key Statistics}

In general, about two million claimants apply for disability annually. Approximately 400,000 are granted benefits at the state DDS initial intake level and another 75,000 on reconsideration. ${ }^{126}$ Those who continue with their appeals then proceed to the ALJ phase.

\section{A. ALJ Hearing Stage}

The SSA adjudication system is probably the largest system of trialtype adjudication in the world. In FY 1999, the Office of Hearings and Appeals ("OHA") reported 524,644 case filings. In FY 2000, the number dropped by 3 percent to 507,010. This compares to a dramatically lower figure in 1969 of 27,000. ALJ dispositions have exceeded filings in recent years, with 596,999 in FY 1999 and 584,546 in FY 2000. However, the pending caseload remains quite high, with 239,370 at the end of FY $2000 .^{127}$

Cases decided by ALJs reverse claim denials by the State DDS offices at a remarkably high rate. Favorable ALJ decisions to claimants were 66 percent in 2000, and were over 70 percent from 1990-95. But variations by state ranged from 86 percent (Maine) to 35 percent (DC). ${ }^{128}$ This reversal rate is especially high in Disability

\footnotetext{
126 See SSAB, DiSABILITY DECISION MAKING, supra note 26, at 86 (Chart 67) (reproduced in Appendix B of this Report, infra).

127 These figures are from Soc. Sec. Admin., Social SECurity Bulletin, AnNual Statistical SUPPLEMENT 117, Table 2.F9 (2000). For FY 2003, the estimate is for the pending caseload to rise to 537,000. See SOCIAL SECURITY ADMINISTRATION, FISCAL YEAR 2003 JUSTIFICATION OF ESTIMATES FOR APPROPRIATIONS COMMITTEES 104 (forthcoming 2002).

${ }^{128}$ See SSAB, DISABILITY DECISION MAKING, supra note 26, at 70.
} 
Insurance cases, in which claimants receive favorable decisions in over 75 percent of cases; in Supplemental Security Income (SSI) cases, the figure is just over 50 percent. ${ }^{129}$

The percentage of DI and SSI claimants represented by attorneys at ALJ hearings has nearly doubled (to 70 percent) since 1977 and representation by non-attorneys has gone from about 10 percent to 18 percent. Only about 12 percent of all claimants are unrepresented. ${ }^{130}$

The average processing time in FY 2000 at the ALJ stage was 274 days, down from a peak of 386 days in $1997 .{ }^{131}$

\section{B. Appeals Council}

Appeals Council receipts have fluctuated at slightly over 100,000: 110,159 in FY 1998; 115,150 in FY 1999; and 100,950 in FY 2000. As with the hearing level, the Appeals Council has been able to increase its disposition rate with 101,877 dispositions in FY 1998; 91,173 in FY 1999; and 134,191 in FY 2000. Pending cases at the Appeals went from 120,548 at the end of FY 1998 to 144,525 at the end of FY 1999, to 113,323 at the end of FY 2000. ${ }^{132}$

Not all of the cases the Appeals Council receives are requests for review from claimants, however. In FY 2000, for example, the dispositions listed above represented 106,358 requests for review; 9,813 court remands; 14,363 reviews of new court cases; and 5,360 quality assurance and special reviews. ${ }^{133}$

\footnotetext{
${ }^{129} I d$. at 22 .

${ }^{130} I d$. at 73 .

${ }^{131} I d$. at 81 .

${ }^{132}$ See Soc. Sec. Admin., Social Security Bulletin, AnNual Statistical Supplement, 117, Table 2.F11 (2000).

${ }^{133}$ See SSAB, DISABILITY DECISION MAKING, supra note 26, at 76.
} 
In 2000, about 76 percent of the Appeals Council decisions were denials of review. About 19 percent were remands (60 percent of which ultimately result in allowances), and a small percentage were allowances or dismissals. ${ }^{134}$

Requests to the Appeals Council to review ALJ decisions increased 54 percent between 1994 and 2000, and average processing time more than quadrupled from approximately 115 days to 505 days. ${ }^{135}$

\section{Courts}

\section{District court filings}

Challenges to SSA decisions in federal district court rose steadily in the 1980s and then dropped significantly in the 1990s, only to begin rising steadily again in the last few years. In FY 1980, there were 7,814 SSA cases filed in the federal district courts. By FY 1984, the high water mark, the total had reached 27,903. This large number has been attributed to the aggressive "continuing disability review" ("CDR") policy and nonacquiescence policies pursued by SSA from 1981-84. ${ }^{136}$ By FY 1990, with the termination of the CDR policies, the caseload had quieted down to approximately 5,600. It then see-sawed from approximately 12,000 in FY 1993 to approximately 8,500 in FY 1996. At that point, SSA began a program of increased CDRs again ${ }^{137}$ and the caseload began to rise fairly steadily again starting in $1997 .{ }^{138}$ According to the Administrative Office for the U.S. Courts, in the one-year period ending September 30, 1997, the total

\footnotetext{
${ }^{134} I d$. at 77.

${ }^{135} I d$. at 78 .

${ }^{136}$ Rains, supra note 106 , at 7-8.

${ }^{137}$ See SSAB, DISABILITY DECISION MAKING, supra note 26, at 28.

${ }^{138}$ As stated above, CDRs may not be a significant factor. See the discussion in the text at note 107.
} 
number of SSA cases commenced in the district court was $13,605 .^{139}$ In the next year, the number jumped to $14,552,{ }^{140}$ then dropped slightly to $13,920{ }^{141}$ but then, in the most recent reported one-year period (ending September 30, 2000), it rose to its highest level since the $1980 \mathrm{~s}-15,829 .{ }^{142}$ In 2000 , fifteen district courts reported over 300 cases. $^{143}$ The Eastern District of Kentucky led the way with 831 .

In FY 2000, the district courts remanded 48 percent of the cases and reversed another 6.15 percent outright. About 60 percent of remands eventually become allowances. ${ }^{144}$ The average processing time at the federal district court stage is about 18 months. ${ }^{145}$

These statistics are not uniform throughout the district courts. The data shows that district courts have widely different approaches to disability appeals. Looking at districts with over 100 cases in FY 2000, there were two districts (N.D.N.Y. and N.D. Tex.) that did not grant a single allowance for disability claimants. At the other end of the scale, W.D.Ark. granted 24.62 percent and S.D.N.Y. granted 27.87 percent of claimants an allowance. ${ }^{146}$ The federal district court average allowance rate is 6.15

139 ADMIN. OFFICE OF THE U.S. COURTS, ANNUAL REP. OF THE DIR., JUDICIAL BUSINESS OF THE UNITED STATES COURTS 1997, available at http://www.uscourts.gov/judicial_business/contents.html. Table S-9.

140 ADMIN. OFFICE OF THE U.S. COURTS, ANNUAL REP. OF THE DiR., JUDICIAL BUSINESS OF THE UNITED STATES COURTS 1998, available at http://www.uscourts.gov/dirrpt98/index.html. Table S-9.

141 Admin. OfFice of the U.S. COURTS, ANNUAL ReP. OF THE DiR., JUdicial Business OF THE UNITED STATES COURTS 1999, available at http://www.uscourts.gov/judbus1999/supps.html. Table S-9.

142 JUDICIAL BUSINESS 2000, supra note 26, Table S-9.

${ }^{143}$ See id. These included E-NY, E-PA, W-PA, MD, W-VA, S-WV, E-KY, N-OH, ETN, E-AR, ECA, C $\mathrm{CA}, \mathrm{E}-\mathrm{WA}, \mathrm{N}-\mathrm{AL}$, and M-FL

${ }^{144}$ SSAB, DISABILITY DECISION MAKING, supra note 26, at 86. For similar figures for FY 1999, see also

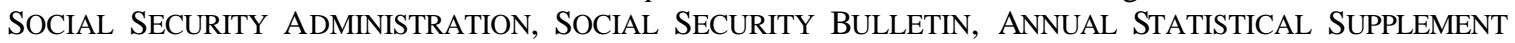
117, Table 2.F10 (2000).

${ }^{145}$ SSAB, DISABILITY DECISION MAKING, supra note 26, at 103.

${ }^{146}$ See infra, Appendix A. An allowance is a reversal of the Appeals Council decis ion resulting in the payment of benefits to the claimant without a remand. The federal district court civil caseload dataset used 
percent. The actual allowance rate for claimants after an appeal to the federal courts is higher than 6.15 percent since 48 percent of cases are remanded and 60 percent of such cases result in grants by the Appeals Council. This means that approximately 28.8 percent of appeals to the district courts result in an allowance after remand $(3,904$ of 13,681 cases). When added to the 6.15 percent allowance rate, this ultimately results in awards for about 35 percent of claimants who appeal Appeals Council denials to district courts. (Of course, the remanded cases would experience a delayed payment compared to those directly awarded an allowance by the district court.)

There are no data on the remand rate per district, but one might assume that such variations in the allowance rate would imply that the remand rate would display similar variations. $^{147}$ It is thus hard not to conclude that disability cases receive non- uniform treatment among districts.

\section{Court of appeals filings}

Statistics on SSA cases in the courts of appeals are harder to find. Total appeals from district courts to courts of appeals in SSA cases were 699 in FY 1997; 862 in FY 1998, 904 in FY 1999; and 845 in FY 2000. ${ }^{148}$ This last figure represents about 2.5 percent of the total appeals of civil cases lodged in the courts of appeals. In FY 2000, there were 942 SSA cases terminated in the courts of appeals, including 726

to compile these figures is provided free on the Internet by Professors Theodore Eisenberg and Kevin M. Clermont of Cornell University Law School. See Eisenberg \& Clermont, supra note 47.

147 See infra, Appendix A.

${ }^{148}$ Data is from Table B-1A, contained in ADMIN. OFFICE OF THE U.S. COURTS, ANNUAL REP. OF THE DIR., JUDICIAL BUSINESS OF THE UNITED STATES COURTS 1997-2000, available at http://www.uscourts.gov/judbususc/judbus.html. This compares with 151 cases appealed from the CAVC to the CAFC in the year ending March 31, 2001, see ADMINISTRATIVE OFFICE OF THE U.S. COURTS, FEDERAL Judicial CASElOAD STATISTIC [SIC], Table B-8 (Mar. 31, 2001), available at http://www.uscourts.gov/caseload2001/tables/b08mar01.pdf. See also Levy, supra, note 10 at 480, 
determinations on the merits. Of these, only 175 required oral argument, the rest were decided after submission of briefs only. ${ }^{149}$ No data is available on reversal rates or time frames for review at the court of appeals stage.

\section{$\underline{\text { VII. Veterans Benefits Appeals Process }}$}

The process for judicial review for veterans' disability benefits claims dates back only to $1988 .^{150}$ Before that no judicial review was available. It is instructive to describe the post-1988 process in some detail, because the process now involves an administrative adjudication of benefits claims, followed by review by an Article I court, with review of legal issues by the Article III Court of Appeals for the Federal Circuit.

\section{A. Basic Review Structure}

A claimant veteran first submits an application for benefits. If the claimant is dissatisfied with the benefits determination by the rating board that initially decides the claim, there are three main appeals levels: (1) review by the Board of Veteran's Appeals ("BVA"); (2) review by the Article I U.S. Court of Appeals for Veterans Claims ("CAVC"); ${ }^{151}$ and (3) review by the Article III Court of Appeals for the Federal Circuit ("CAFC") on questions of law only. Of course, certiorari review by the U.S. Supreme Court is available but there has only been one case accepted by the Court since $1988 .{ }^{152}$ It is also possible for the veteran to refile the claim. ${ }^{153}$

providing a table of filings in the courts of appeals from 1965 to 1988 . Until 1976, the number never exceeded 300. The high water mark was 1,204 in 1984. By 1988, the number had dropped to 992.

149 See JUDICIAL BUSINESS 2000, supra note 26, Table B-1A, available at http://www.uscourts.gov/judbus2000/appendices /b01asep00.pdf.

${ }^{150}$ See Veterans’ Judicial Review Act, Pub. L. No. 100-687, §301, 102 Stat. 4105, 4113 (1988).

151 The court was named the U.S. Court of Veterans Appeals (COVA) until March 1, 1999. See CAVC, ABOUT THE COURT, available at http://www.vetapp.uscourts.gov/AboutCourt/CourtFacts.asp.

152 Brown v. Gardner, 513 U.S. 115 (1994) (affirming CAVC and Federal Circuit decisions holding that the VA incorrectly required a fault requirement as a condition of VA disability payments when a veteran's 


\section{The initial filing}

When a veteran initially files a Compensation or Pension disability ("C\&P") claim, the Veterans Benefits Administration ("VBA") makes the initial decision regarding claims. The VBA is divided into 58 regional offices ${ }^{154}$ and has a staff of 12,008. ${ }^{155}$ The VBA makes decisions regarding 37 separate C\&P programs. ${ }^{156}$

Once a claim comes into the office, the VBA must gather pertinent information. This may include a C\&P medical examination. ${ }^{157}$ For many, but not all, C\&P programs, the veteran must show that the disability occurred as a result of wartime military service. ${ }^{158}$ If so, the VBA must pull the veteran's service and prior medical records. The records may come from the Veterans Health Administration, Department of Defense, the National Personnel Record Center ("NPRC"), VBA Records Management Center, or private medical or income records. ${ }^{159}$ This process is hampered for older veterans'

non-war related injury was exaggerated during surgery at a VA hospital). The Supreme Court is granted appellate jurisdiction over VA disability cases from the Federal Circuit under 28 U.S.C. § 1254.

153 Gary O'Connor, Rendering to Caesar: A Response to Professor O'Reilly, 53 ADMIN. L. REV. 343, 35355 (2001).

${ }^{154}$ Documents reviewed list both 57 and 58 offices.

155 VA Claims PROCESSing TASK Force, ReP. TO THE SECRETARY OF VeTERANS AfFAIRS 22-23 (Oct. 2001) [hereinafter VA TASK FORCE] (displaying a graph showing that the work force was at a high of 13,714 in 1993 and decreased slowly to 11,250 in 1998-99 and then slightly increasing to 12,008 in 2001).

${ }^{156} I d$. at 8-9. The VBA work is not limited solely to the $37 \mathrm{C} \& \mathrm{P}$ programs.

157 The VBA is currently running pilot programs of outsourcing this C\&P medical evaluations from the VHA to private doctors. See id. at 20-21.

158 Active duty injuries that result in a disability are filed as a compensation disability and the program has 2.3 million beneficiaries. The 364,000 pension disability recipients are low-income veterans who received a serious disability after service. See VBA, WHAT ARE THE STEPS IN PROCESSING My ClAIM?, at http://www.vba.va.gov/ro/west/phenx/claims.htm (last updated Apr. 4, 2000).

${ }^{159}$ Id. at 47-50 
claims, because a 1973 fire at the NPRC in St. Louis destroyed eighty percent of Army records from before 1960 and a large portion of other records. ${ }^{160}$

After collecting the data, the VBA uses up to five dozen separate factors in "rating cases."161 The average processing time varies on a monthly basis; in November 2000 the processing time was 158.7 days and in July 2001 it was 184.2 days ${ }^{162}$ while the average time for FY 1999 was 205 days. ${ }^{163}$ The VBA's website states that the time from initial filing to a final Regional Office decision is four to ten months depending on the complexity of the case and the retrieval of records. ${ }^{164}$ Cases are "rated" "to reflect a loss of earnings capacity."165 Unlike the "all or nothing" approach of the social security program, the ratings are scaled in 10 percent increments from 0 to 100 percent. ${ }^{166}$ In 2001, a 10 percent rating would pay $\$ 101$ per month while a 100 percent rating would pay $\$ 2,107$ per month. ${ }^{167}$ No data from the VBA, BVA, VA, or other sources has revealed the number or percent of cases ending favorably for claimants at the initial Regional Office level. The statistic is apparently not kept. This may be partially due to the fact that even cases resulting in a payment to the veteran may be appealed if the veteran is dissatisfied with the rating.

\footnotetext{
${ }^{160}$ Dep't of Veterans Affairs, Fact Sheet: Facts About the 1973 St. Louis Fire and Lost Records (Oct. 27, 1999), available at http://www.va.gov/pressrel/99stlou.htm.

161 Dep't of Veterans Affairs, Fact Sheet: VA Disability Compensation Claims Processing, May 2001, at http://www.va.org/pressrel/claimpro.htm.

162 VA TASK FORCE, supra note 152, at 1-2.

${ }^{163}$ Statement of Rick Surratt, Deputy National Legislative Director, Disabled American Veterans, Before the Comm. on Veterans' Affairs, Subcomm. on Oversight \& Investigations, U.S. House of Rep., May 18, 2000 [hereinafter Surratt DAV Testimony 2000], at http://www.dav.org/voters/testimony_claims_ 20000518_print.html.

${ }^{164}$ See VBA, WHAT ARE THE STEPS IN PROCESSING MY ClAIM?, supra note 155.

${ }^{165}$ Fact Sheet, supra note 157.

${ }^{166} I d$.

${ }^{167}$ Id .
} 
The initial stage takes a veteran seven months (205 days) on average from filing to notification of the decision. ${ }^{168}$ The VA's goal is 74 days. ${ }^{169}$ The delays are primarily due to data retrieval delays and the volume of cases that need to be reworked after remand from the BVA or CAVC. One potential benefit of the lengthening of the initial process ${ }^{170}$ may be greater accuracy at the Regional Office level. Remands from the BVA have dropped from 50 percent in the early 1990 s to 29.9 percent. $^{171}$

\section{The Board of Veterans Appeals}

Veterans may appeal decisions to the Board of Veterans Appeals. The BVA is an appellate body within the VA, established in 1933, and consists of over sixty members, appointed by the President upon the recommendations of the Secretary. ${ }^{172}$ Currently all members of the BVA are attorneys. ${ }^{173}$ Since 1992 , decisions are made by individual members and not by panels. ${ }^{174}$ As noted above, a large number of cases that come before the court are remanded back to the VBA regional offices. There are two main reasons for

\footnotetext{
${ }^{168} I d$.

${ }^{169} I d$.

170 See Office of Inspector Gen., Dep't of Veterans Affairs, AUDIT REP. \#5D2-B01-013, (Mar. 15, 1995) (discussing the lengthening of the processing time from 106 days in 1988 to 212 days in 1995; and mentioning the 50 percent remand rate in 1995).

${ }^{171}$ Surratt, DAV Testimony 2000, supra note 160 (describing a 50 percent remand rate from the BVA to Regional Offices in 1992); VA TASK FORCE, supra note 152, at 35. In 1997, the BVA remanded 45.2 percent of cases. See id. at 35.

172 See REPORT OF THE CHAIRMAN, BOARD OF VETERANS' APPEALS (FY 2000) 2-3 (noting that BVA was created by Exec. Order 6230, and now has 67 authorized positions).

173 In the past, a mix of attorneys and physicians sat on the BVA. See Fox, supra note 9, at 18 (2000) (citing Committee on Veterans' Affairs, United States Senate, Veterans Administration Board of Veterans' Appeals 40th Anniversary 1, 3 (1973))

174 See Gary O'Connor, Did Decide or Should Have Decided: Issue Exhaustion and the Veterans Benefits Appeals Process, 49 AM. U. L. REV. 1279, 1284-85 (2000).
} 
the volume of remands: (1) the open case file system, and (2) insufficient C\&P medical examinations (33 percent of all remands). ${ }^{175}$

The open case file is part of the VA's pro-claimant stance that Congress intended. This allows the veteran to add new information or evidence at anytime prior to a final VBA decision. The entire VBA structure is designed to be non-adversarial and lawyers are prohibited in the Regional Office process. Although lawyers are allowed at the BVA level, few oral arguments are held and only 6.3 percent of claimants are represented by attorneys. ${ }^{176}$ The open case file allows the veteran to prepare a more favorable file after an initial undesirable rating. However, when new evidence is added to the file, the BVA must typically remand the case for the Regional Office to consider. Commentators have suggested the need for either a closed case $\operatorname{system}^{177}$ or an optional de novo review at the Regional Office before the veteran appeals to the BVA. ${ }^{178}$ A closed case system would likely eliminate the non-adversarial atmosphere because of the necessity to prepare the record "litigation" before the BVA. The preferable answer may be true de novo review by the BVA-meaning that the BVA would decide a case when new evidence was submitted instead of remanding the case to the Regional Office. ${ }^{179}$

\footnotetext{
175 See VA TASK FORCE, supra note 152, at 20.

176 See REPORT OF THE CHAIRMAN, supra note 169 at 6. This is an increase from 5.1 percent the previous year. Interestingly, BVA statistics show that, in FY 2000, claimants represented by attorneys did not achieve a higher rate of allowances than those represented by VSOs, but they did receive a significantly higher rate of remands. Unrepresented claimants did markedly worse on both counts. See id at 34.

177 See AUDIT REPORT, supra note 167, at 6-7 (calling for BVA and CAVC to review evidence as it existed when the initial decision was reached).

178 See VA TASK FORCE supra note 152, at 15.

${ }^{179}$ Cf. FOX, supra note 9, at 84 (recommending that the BVA be allowed to "build a proper hearing record without the need to remand the case to the regional office.")
} 
BVA response time in FY 2000 was 220 days, up from 197 in FY 98 but markedly improved from a peak of 781 days at the end of FY $94 .{ }^{180}$

\section{Court of Appeals for Veterans Claims ("CAVC")}

Only the claimant, and not the VA, may appeal a BVA decision to the CAVC. ${ }^{181}$ This makes logical sense, as the BVA is part of the VA and makes decisions in the shoes of the Secretary of Veterans Affairs.

The CAVC is a seven-member court nominated by the President and confirmed by the Senate for fifteen-year terms. ${ }^{182}$ BVA decisions are reviewed under the clearly erroneous standard. ${ }^{183}$ Initial decisions are made by a single judge, although a veteran can move for panel review by three judges or en banc review after the initial court decision. ${ }^{184}$ Only panel or en banc decisions have precedential value.

The addition of the CAVC (originally called Court of Veterans Appeals) marked a sea change to the veterans claims process, which until its creation in 1988 did not include any judicial review. Its record, however, has proved to be a mixed one. ${ }^{185}$ On the one hand, judicial oversight was brought to the system for the first time. On the other,

\footnotetext{
${ }^{180}$ See REPORT OF THE CHAIRMAN, supra note 169 at 5. "Response time" is defined as "the number of days it would take BVA to render decisions on all pending certified appeals at the processing rate of the immediately proceeding one-year time frame." $I d$. at 36 . The BVA attributes this improvement to its making more use of videoconference hearings, as authorized by Congress in the Board of Veterans' Appeals Administrative Procedures Improvement Act of 1994, Pub. L. No. 103-271. Id. at 6.

18138 U.S.C. $\S 7252$.

182 Congress has recently authorized two additional judges to serve during the period January 1, 2002, through August 15, 2005. See the Veterans Education and Benefits Expansion Act of 2000, Pub. L. No. 107-103 § 603 (Dec. 27. 2001).

18338 U.S.C. $§ 7261(\mathrm{a})(4) ;$ Hensley v. West, 212 F.3d 1255 (Fed. Cir. 2000).

${ }^{184}$ U.S. Vet. App. R. 35(c). See O’Connor, supra note 150, at350-51.

${ }^{185}$ Compare James O'Reilly, Burying Caesar, 53 ADMIN. L. REV. 223 (2001) (arguing CAVC, in effect, duplicates BVA, adds delays without efficiency benefits, and is a failed experiment because both BVA and CAVC are "captured" by the veteran community) with O'Connor, supra note 150, at 350-51 (rebutting many of O'Reilly's criticisms).
} 
however, the addition of the adversarial appeal to the court layered on top of a nonadversarial system that has not been modified to take account of the new appeals system, has led to longer processing times at all levels of the system (see below). In a sense, it raises the recurring question of comparing the values of accuracy versus timeliness.

Even though the CAVC process is an adversarial one, the court allows oral arguments in only 1 percent of the cases. The file is closed and the CAVC only reviews evidence based on the record at the time of the final BVA decision. ${ }^{186}$ The CAVC reviews law de novo and facts under the clearly erroneous standard. ${ }^{187}$

The caseload ${ }^{188}$ has fluctuated quite widely in the past seven years. New cases have ranged from 1,279 in 1995 to 2,442 in 2000 (the average is 2,090). Dismissals and affirmances have averaged about 54 percent of all terminations. Partial affirmances average about 12-15 percent of all terminations. Unfortunately the court's annual reports lumps together reversals/vacations/remands, making it impossible to parse the remaining third of the terminations - and critics have claimed that too many of these are remands. ${ }^{189}$

The time frame for CAVC decisionmaking, from filing to disposition has averaged around one year for the last seven years. ${ }^{190}$

\section{Limited review by the Court of Appeals for the Federal Circuit ("CAFC")}

Either the VA or the claimant may appeal CAVC decisions to the Court of Appeals for the CAFC. ${ }^{191}$

\footnotetext{
${ }^{186}$ See Gary O'Connor, supra note 171, at 1292-93.

18738 U.S.C. $\S 7261$.

${ }^{188}$ The statistics are from U.S. COURT OF APPEALS FOR THE FED. CIRCUIT, ANNUAL REPORTS, ABOUT THE COURT, available at http://www.vetapp.gov/AboutCourt/AnnualReport.asp.

${ }^{189}$ See O'Reilly, supra note 182, at 228-29.

${ }^{190}$ See id.
} 
Under the veterans judicial review statute, the CAFC only has jurisdiction of appeals from the CAVC that raise legal, as opposed to factual, issues, i.e., constitutional, or statutory issues or a challenge to a regulation that has been applied to the case. The rate of appeals to the CAFC, is, not surprisingly, quite low (only 194 filings in 1999 (compared to 2,442 in CAVC), and there is a high rate of jurisdictional dismissals as well. The CAFC only reversed nineteen decisions of the CAVC in 1999 (though the number of remands is not known). Its jurisdiction is so limited and it hears such a miniscule percent of claims that the court's role is discussed very little in reports by interest groups or the VA Claims Processing Task Force.

\section{Refiling}

Once a decision is final, the veteran still has two options that are not available to SSA benefit claimants: (1) reopening a claim and/or (2) requesting a revision. As will be discussed below in the statistics section, a majority of $\mathrm{C} \& \mathrm{P}$ filings are not new matters. Indeed, a veteran can reopen a claim as many times as s/he wishes if "new and material evidence" can be provided. Nor is there a time limit on reopening a claim. If the veteran submits new evidence, the agency is required to take another look at the former claim. ${ }^{192}$ This removes almost all issue- and claim-preclusion effects of a VA decision.

Revisions (akin to a request for reconsideration) have no time limit, but can only be requested once per claim. A revision can only be granted if a "clear and unmistakable error" is found in a prior decision.

B. Delays in the Process

\footnotetext{
19138 U.S.C. $\$ 7292$.

${ }^{192}$ See O'Connor supra note 150, at 352-53.
} 
The average time from the date the claimant files a Notice of Disagreement until the case is made final by the VBA-including final decisions by the regional office on remand or later decision by the BVA—was 650 days in 2001 according to the VA's FY 2001 budget report. The VA Claims Processing Task Force estimates the average time at 796 days. When cases are remanded to the VBA Regional Office, they are then placed back in the system to be processed along with initial filings. ${ }^{193}$

The delays at the BVA level appear to be the greatest problem with the VA appeals structure. In addition to the fact that there are too many remands, delays after the remand are caused by the failure of VBA Regional Offices to give remands priority.

\section{Representation}

Claimants may be represented by an attorney or a representative from a Veteran Service Organization. Under the VA appeals system, claimants and their attorneys or representatives must meet a complex set of requirements. ${ }^{194}$ Attorneys and representatives may only collect a fee for representation if: (1) the Notice of Disagreement was filed after Nov. 18, 1988; (2) the BVA has already issued a decision regarding the issues; and (3) the attorney-client relationship began at least one year after the BVA decision. ${ }^{195}$ This, of course, makes it harder to attract lawyers as representatives. Thus, even during the BVA appeals stage, only 5 percent of veterans have legal counsel. However, an additional 84 percent have a Veteran Service

\footnotetext{
${ }^{193}$ See id. at 27-29. O'Reilly cites a figure of 745 days, supra note 182, at 226.

${ }^{194}$ See NAT'L ORG. OF VETERANS' AdVOCATES, WHY A VETERAN SHOULD BE REPRESENTED, available at http://www.vetadvocates.com/why_choose.htm.

${ }^{195}$ FoX, supra note 9 , at 40 (citing 38 U.S.C. § 5904(c)(1) (1994)).
} 
Organization ("VSO") representative. ${ }^{196}$ Once the case goes to the CAVC, however, the fee payment limitations are removed, (although the fees charged are still reviewable for reasonableness and may not exceed 20 percent of the past-due benefits awarded ${ }^{197}$ ), and the rate of attorney representation increases significantly. At the CAVC level, 45 percent have an attorney when they file their appeal with the CAVC and 71 percent have an attorney by the end of the CAVC process. ${ }^{198}$

VSO representatives are provided free to veterans by Veteran Service Organizations. However, in the past, many such representatives lacked the ability to gather evidence for a case. Since 1999, over one thousand VSORs have been trained in the data retrieval process and can request data to quicken the case filing preparation. ${ }^{199}$ The VA is attempting to increase the involvement of VSO representatives while the CAVC is attempting to increase the involvement of attorneys. ${ }^{200}$

\section{Statistics}

The following statistics are from FY 1999. Although more recent data exists for several levels of the review process, this is the most recent year for VBA filings. ${ }^{201}$

\footnotetext{
196 Until 1988, a long-standing fee limitation of $\$ 10$ per case was imposed by statute. The Supreme Court upheld this limitation against a due process challenge in Walters v. Nat'l Ass'n of Radiation Survivors, 473 U.S. 305, 323 (1985) (Rehnquist J.) (describing the process as one of "rational paternalism.") Veteran service organizations (VSOs) supported this attorney fee limitation because they argued that attorneys would transform a paternalistic system in to an adversarial system. They also benefited from the system because it essentially gave them a monopoly over representation-because veterans could not hire attorneys, they joined VSOs for their pro bono representation. The current attorney's fee payment rules have a similar effect.

19738 U.S.C. $\$ \$ 5904(c)(2)$ and (d)(1).

198 U.S. COURT OF APPEALS FOR THE FEDERAL CIRCUIT, ANNUAL REPORTS, ABOUT THE COURT, available at http://www.vetapp.gov/AboutCourt/AnnualReport.asp.

199 See VA TASK FORCE, supra note 152, at 59-60.

${ }^{200}$ Compare id. at 26-27, 59-60; with O'Connor supra note 150, at 355-57.

${ }^{201}$ It should be noted that no statistics are available for the number or percent of initial filing decisions that award payment to the veteran. The VBA does provide statistics for new C\&P benefit recipients. In 1999, 133,906 veterans began receiving $\mathrm{C} \& \mathrm{P}$ benefits. However, of the more than two million filings per year,
} 


\begin{tabular}{|c|c|c|c|c|c|c|c|}
\hline & 吻 & 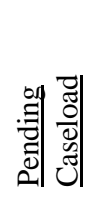 & 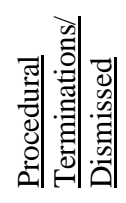 & $\begin{array}{l}\text { : } \\
\text { : } \\
\text { : } \\
\text { : }\end{array}$ & 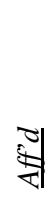 & 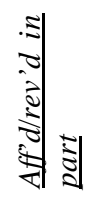 & 羿 \\
\hline 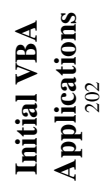 & $\begin{array}{l}\text { 点 } \\
\stackrel{-}{5} \\
\text { i } \\
\text { i }\end{array}$ &  & & & & & \\
\hline 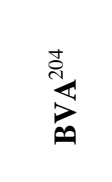 & $\frac{\tilde{\tilde{N}}}{\tilde{\lambda}}$ & $\begin{array}{l}\text { q } \\
\infty \\
\vdots \\
\sigma\end{array}$ & & 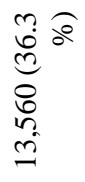 & $\begin{array}{l}\vec{\infty} \\
\infty \\
\pm\end{array}$ & $\mathbb{Z}$ & 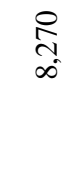 \\
\hline Uू. & 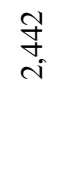 & $\mathbb{Z}$ & î & 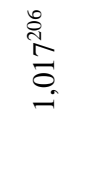 & రి & ? & 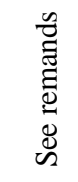 \\
\hline 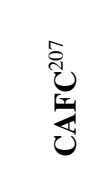 & $\stackrel{\Delta}{\triangle}$ & $\hat{\sigma}$ & $\varangle$ & $\mathbb{Z}$ & 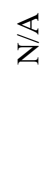 & $\overleftrightarrow{Z}$ & $\begin{array}{r}20 \\
\stackrel{\infty}{=}\end{array}$ \\
\hline
\end{tabular}

the VBA does not report the number of filings for a change in benefits versus the number of first time filings. Moreover, an approved claim awarded in 1999 might not have been filed in 1999, so one cannot simply divide the number of filings in 1999 by the number of allowances in that year.

202 See Surratt DAV Testimony 2000, supra note 160, at 7.

203 This figure includes the over 27,000 remands from the BVA. See id. at 7-8.

${ }^{204}$ See VA TASK FORCE, supra note 152, at 35.

205 See CAVC, ANNUAL REPORTS (providing data for FY 1999 ending on Sept. 30), at http://www.vetapp.uscourts.gov/AboutCourt/AnnualReport.asp.

206 This figure is for "reversed/vacated \& remanded" for FY 1999. It does not include partial reversals/remands. It compares to 2256 "merits terminations as a whole." It does not match the 1,380 remands reported by the VA Claims Processing Task Force in table S-7.1 at page 35. Moreover, these figure are the remands ordered in 1999 and not the number of remands ordered from the cases filed with the CAVC during 1999. Some of the remand cases date from 1993, as described in Table S-1.4 on page 30 of the VA TASK FORCE REPORT, supra note 152.

207 See U.S. COURT OF APPEALS FOR THE FED. GRCUIT, APPEALS FILED, TERMINATED, AND PENDING DURING THE 12-MONTH PERIOD ENDING SEPTEMBER 30, 1999, at http://www.fedcir.gov/pdf/b08sep99.pdf. Updated figures for appeals from CAVC for the period ending March 31, 2001 are: Pending April 1, 2000-158; Filed-151; Terminations by Judges - 176; Terminations other-57; percent reversed 22 percent, pending March 31, 2001-76. See Admin. OfFice Of THE U.S. Courts, Federal Judicial 


\section{E. Lessons Learned from the Veterans Benefits Appeals Process.}

The main criticisms of the VA appeals process concern the slowness of the administrative process and the penchant of both the BVA and the CAVC to remand cases back to the rating boards. This leads to lengthy delays in the remanded cases because they are not placed at the beginning of the queue. One explanation for this tendency is the inadequacy of the administrative record caused by the informality of the rating board process and the lack of representation at that level. ${ }^{208}$ Additionally, many C\&P programs require the claimant to prove that the disability occurred as a result of combat. The added research and paperwork requests from other government agencies causes delay in the VA system that would not concern the SSA if the SSA Court were to be established. ${ }^{209}$ Critics of the CAVC have also accused it of taking the easy way out and remanding cases on one issue when another issue raised would have resolved the case in the claimant's favor.

Most critics calling for VA disability appeals reform have concentrated on reforming the current system. There is a narrow range of reforms that is typically discussed. The VA Claims Processing Task Force proposed that the BVA not have remand authority. Instead, BVA would retain jurisdiction while the record was reworked

\footnotetext{
CASELOAD STATISTIC [SIC], Table B-8, (Mar. 31, 2001) available at http://www.uscourts.gov /caseload2001/tables/b08mar01.pdf.

208 See Gary O'Connor, supra note 150, at 363 (stating BVA "does not have a neat, organized record") and $i d$ at 383 (stating in perhaps the vast majority of remanded cases, "there is not enough evidence in the record at the time of a CAVC appeal for the court to grant benefits").

${ }^{209}$ On average, the VBA waits 53 days for a Service Verification and 83 days for Service Medical Records and a total of 123 days for information from the NPRC in St. Louis. See VA TASK FORCE, supra note 152, at 22,54 . To compound the problem of remands for insufficient evidence, remanded cases are not given priority for record retrieval. $I d$. at 48 .
} 
and completed. ${ }^{210}$ Professor Fox also favors a BVA centered reform (and the VA Claims Processing Task Force's proposal). He recommends that the reconsideration before a Hearing Officer at the VBA be eliminated, and instead, the case should go directly to the BVA. To complete this change, Fox asserts that the BVA members should be turned into ALJs as in the SSA system. ${ }^{211}$ Professor Sidney Shapiro and Ronald Smith of the Disabled American Veterans, concur with Fox on turning the BVA into ALJs. However, they focus their attention on the CAVC. They argue that the system would be streamlined if the CAVC would resolve all possible allegations of error before remanding, thus reducing the need for a future appeal. Additionally, they would like the CAVC to enforce deadlines on remanded cases to force the BVA and the Regional Offices to reduce inordinate time delays. ${ }^{212}$ The most vocal critic of the VA disability structure is Professor O'Reilly. He argues that the CAVC and the BVA are duplicative and wasteful, instead, he would like to adopt the SSA system of review by generalist Article III judges. ${ }^{213}$

These issues are, to some extent, a product of the difference between the underlying informal administrative process at the VA and that at SSA. At the SSA, the more formal ALJ process and the more prevalent participation of attorneys (in 70 percent of cases) produce a better record. However, the CAVC does move about 50 percent faster than the district courts do in SSA cases-with terminations completed in twelve months as compared to up to eighteen months for the district courts.

\footnotetext{
210 VA TASK FORCE, supra note 152, at 34-37.

${ }^{211}$ FOX, supra note 9, at 82-84.

212 Sidney Shapiro \& Ronald Smith, Veterans Judicial Review: Is There a Need for Reform? (preliminary draft presented to the ABA Section of Administrative Law and Regulatory Practice Feb. 1, 2002).

${ }^{213}$ See O'Reilly, supra note 182.
} 
If a Social Security Court were to be established, the lessons from the CAVC would be highly relevant. Our discussions with attorneys and other critics of the VA disability process (including representatives of the Disabled American Veterans) reveals that, while they believe the system has flaws, it is fixable; and they do not favor moving to the SSA-district court review process. ${ }^{214}$

$\underline{\text { VIII. An International Comparison-The Australian Social Security Appeals Tribunal }}$

Numerous countries around the world use a social security tribunal of some kind to decide disability claims. ${ }^{215}$ Most of these are the equivalent to the SSA ALJ adjudication. Australia's Social Security Appeals Tribunal, however, is a review tribunal that is closer to an Article I SSA Court.

Australia has a national Administrative Appeals Tribunal ("AAT") that hears appeals from most administrative agencies, with further review of legal questions available in the regular federal courts. But Australia has also created a specialized national Social Security Appeals Tribunal (“SSAT") (along with several others including a Veterans Review Board, Migration Review Tribunal and Refugee Review Tribunal). ${ }^{216}$ Unlike the other three, the SSAT functions as a first-tier tribunal with second-tier review in the AAT. The SSAT's caseload is actually larger than that of the AAT. In 1996-97, 13,817 applications for review were filed with the SSAT, and 6,849 with the AAT. In

\footnotetext{
${ }^{214}$ Interview with Ronald L. Smith, Chief Appellate Counsel, Disabled American Veterans and Barton L. Stichman, Joint Executive Director, National Veterans Legal Services Program, at ABA Midyear Program, "Veterans Judicial Review: Is There a Need for Reform," (Feb. 1, 2002).

${ }^{215}$ See e.g., Daniel L. Skoler \& Ilene R. Zeitzer, Social Security Appeals Systems: A Nine-Nation Review, INT'L SOC. SEC. REV. Vol. 1, p. 57 (1982).

216 This description is taken from AUSTRALIAN LAW REFORM COMM'N, REVIEW OF THE ADVERSARIAL System of Litigation, Federal Tribunal ProceEdingS, paper 24, chs. 4, 11 (1998) available at http://www.austlii.edu.au/au/other/alrc/publications/issues/24/ALRCIP24.html.
} 
addition, the SSAT has 277 members (including two full time Senior Members, 38 executive members, 97 community and welfare members, 97 legal members, and 42 medical members) as compared to 100 members for the AAT. The SSAT usually operates with three-member panels. The agency may "take back" and alter a decision, without having to wait for the outcome of the SSAT proceedings. The SSAT may, but need not, adjourn its proceedings while the agency reconsiders its decision. The SSAT has the power to affirm, vary or set aside decisions. Where it sets aside a decision it may either substitute a new decision or send the matter back to the agency for reconsideration in accordance with directions or recommendations of the tribunal.

Cases in the SSAT are decided on submissions, written and oral by the applicant, written submission by the Department and, if required, the results of inquirie s made by the SSAT. Oral evidence through witnesses is not usually required. While applications may be decided on the papers or by telephone hearings, most applications are decided through a hearing attended by the applicant. In 1996-97, 86 percent of cases were decided by a hearing (as opposed to those withdrawn or dismissed without a hearing). The SSAT assists applicants to attend hearings by reimbursing reasonable travel expenses, conducts hearings out of its city locations and provides interpreters at no cost to the applicant. The SSAT also provides an informal hearing in which the parties are not generally represented, although the applicant and other parties (but not the respondent agency) may be represented at hearings. Representation is usually by advocates from welfare rights and community legal centers.

The SSAT has set various performance standards for the time taken from registration to finalization of applications. For example, one indicator used is that 75 
percent of appointments for a hearing should be scheduled within 42 days of the SSAT receiving the relevant Department's notice of reasons for a decision. ${ }^{217}$ The SSAT typically conducts a hearing and makes a decision within an hour. In 1996-97, 89.6 percent of decisions were made on the day of hearing. The overall processing time at the SSAT was less than fifteen weeks in over 60 percent of the cases.

One discordant note was sounded about the ability of the SSAT to convene in rural areas in Australia. A witness in rural Geelong, Victoria testified:

[I have been asked] to pass on to you ... [the] many problems with the Social Security Appeals Tribunal being unable to reach rural people. Apparently it is supposed to come to rural areas, including Geelong, but in reality it takes about six months to get a hearing date.

Obviously when people are appealing a decision about social security, that potentially imposes a lot of financial hardship on them. It is a particular problem in hearings about medical matters because in those cases there needs to be a doctor on the hearing panel and apparently it is almost impossible to get a doctor to come to Geelong or other rural areas. Many of those clients have almost no income, so it is very difficult for them to go to Melbourne. Again, I am told that in some cases like that they will try to provide phone hearings, but that is ineffective for many people because it is just not a way they feel they can communicate. ${ }^{218}$

\section{$\underline{\text { IX. Options and Models for Change }}$}

A. Administrative Changes-With No Changes Above the Appeals Council Level

One option, of course would be to limit changes in the system to the administrative level. Many such proposals have been detailed earlier in this Report.

\footnotetext{
${ }^{217}$ SSAT Annual Report 1996-97, 24-26 cited in id.

${ }^{218}$ Testimony of Mr. A. Willis, Principal Solicitor, Before the Law Reform Committee, Inquiry into legal services in rural Victoria, Geelong, (June 29, 2000), available at http://www.parliament.vic.gov.au /lawreform/Legal_Services_Inquiry/Community\%20Legal\%20Services\%20-\%20Moorst\%20Willis\%20\& $\% 20$ Stokie.htm.
} 


\section{B. Split Enforcement Model}

Under this model, ${ }^{219}$ the SSA would be "split" into a rulemaking/initial decisionmaking body on the one hand, and an adjudicatory agency (presumably with two tiers), on the other. This model would require adversary hearings with both claimants and SSA represented in the adjudicatory body. No change would necessarily be required in judicial review, although other such models provide for judicial review directly in the courts of appeals. Would the caseload go down due to more satisfactory decisions at agency level? Would the SSA itself appeal many decisions?

1. Social Security Review Commission ("SSRC"). The archetypal application of this model would involve the creation of an agency staffed with Commissioners and ALJs (and possibly an Intermediate Appeal Board a la the Appeals Council, to keep the need for Commissioners to a manageable level). SSA would still make rules and administer the intake and initial determinations. The SSRC would be to SSA as the independent Occupational Safety and Health Review Commission is to OSHA.

2. United States Office of Hearings and Appeals ("USOHA"). A variation, proposed by SSA's Association of ALJs, would create a quasi-independent adjudicative entity within SSA, headed by a Chief Judge and Deputy Chief Judge appointed by the President. Initial decisions by ALJs would be appealable to an Appellate Panel, composed of ALJs in regional office appointed by Chief Judge for a set term (modeled on Bankruptcy Court Appellate Panel). Existing ALJs would be grandfathered in.

\footnotetext{
${ }^{219}$ For discussions of this model see George Robert Johnson, Jr., The Split-Enforcement Model: Some Conclusions from the OSHA and MSHA Experiences, 39 ADMIN. L. REV. 315, 315 (1987) and Richard H. Fallon, Jr., Enforcing Aviation Safety Regulations: The Case for a Split-Enforcement Model of Agency Adjudication, 4 ADMIN. L.J. AM. U. 389 (1991).
} 


\section{Article I Social Security Court ("SSC")}

1. 95th Congress H.R. 8276 (1977) (Rep. James A. Burke). Would create an Article I court for appeals from SSA decisions relating to the factual issue of disability.

2. 97th Congress H.R. 3865, H.R. 5700 (1981) (Rep. J. J. Pickle). Would create a Review Board composed of GS-16 civil servants ${ }^{220}$ who have had previous experience as ALJs to review ALJ decisions, with review by an Article I Social Security Court with 20 Presidentially appointed, Senate-confirmed (“PA-SC") judges, having ten-year terms to handle appeals in SSA disability cases. Judicial review would be exclusively in Court of Appeals for DC Circuit, but limited to review on constitutional questions and questions of law only.

3. 99th Congress, H.R. 4419 (1986) (Title II). (Rep. William Archer). The "Social Security Procedural Improvements Act of 1986"221 would replace the Appeals Council and district court review with a SSC, with 20 PA-SC judges, including a Chief Judge selected by the President, having ten-year terms, removable only for specified cause after opportunity for a hearing. The Chief Judge may also appoint "commissioners" to assist the judges. To provide uniformity, the bill provides that the decision of one judge becomes that of the court in 30 days, but within this period, the Chief Judge may order review by a three-judge panel. All decisions determined to be precedential by the Chief Judge are to be published. Judges may be removed by the President for cause. Judicial review is exclusively in the Court of Appeals for Federal Circuit (“CAFC”).

\footnotetext{
${ }^{220}$ Note that this level of civil servants has now been largely supplanted by the Senior Executive Service.

${ }^{221}$ Discussed in Rains, supra note 110, at 16-17.
} 
4. 99th Congress, H.R. 4647 (1986) (Rep. Tom Tauke). The "Social Security Reorganization Act of $1986^{, 222}$ would recreate SSA as an independent agency, with the ALJs remaining in the Department of HHS. A non-adversarial proceeding is held before a "hearing officer," with an appeal to an ALJ available on the record of the hearing. Appeals from ALJ decisions could be taken by either party to a SSC. The SSC portion of the bill is similar to H.R 4419, except that the district courts would retain jurisdiction over claims raising constitutional issues or the legality of regulations.

5. 100th Congress H.R. 2117 (1987) (Rep. Archer); H.R. 1666 (1997) (Rep. Tauke) Similar to earlier bills introduced by the same Members.

6. 101st Congress H.R. 2349 (1989) (Title II) (Rep. Archer). Similar. 7. 102nd Congress H.R. 2159(1991)(Title II). (Rep. Archer). Similar. 8. 103rd Congress H.R. 3487 (1993) (Title II). (Rep. Archer). Similar.

No similar post-1993 legislation has been found. A staff member of the House Social Security Subcommittee reported that no such legislation had been introduced in the past few years. ${ }^{223}$

9. Draft DOJ bill. ${ }^{224}$ This draft proposal, circulated in 1985-86, would create an Article I SSC consisting of five regional divisions (Northeastern, Midwestern, Midatlantic, Southeastern and Western, with principal offices in each division-NYC, Chicago, Washington, Atlanta, SF, and Dallas). The court would have 37 judges,

\footnotetext{
${ }^{222} I d$. at 17-19.

${ }^{223}$ Telephone interview with Jeffrey Eckert, Staff Assistant, House Subcommittee on Social Security, January 2002.

${ }^{224}$ Attached to memo, dated May 13, 1985, on file with authors. The proposal is also discussed in Rains, supra note 110, at 1-3 (1987).
} 
including a chief judge, five division chief judges and six associate judges in each division. The judges would serve nine-year terms (staggered to start). Judicial review would be in the CAFC (at the discretion of the CAFC, except that if the Secretary certifies that the case has "broad or significant implications in the administration or interpretation of the social security laws," the CAFC must hear the appeal). The SSC would be administered by a Council made up of the Chief Judge, the division chief judges and one associate judge from each division. The Council could sit as an en banc review panel. [Note-there is no evidence that this bill was ever introduced. ${ }^{225}$ ]

10. Similar SSC model, but with judicial review in geographical circuits. In 1987, Antonin Scalia suggested certiorari review of Social Security Court decisions by courts of appeals. $^{226}$

D. Article I Disability Court.

Proposed by the ABA Standing Committee on Federal Judicial Improvements (August 1984). This resolution, which was never submitted to the House of Delegates, called for creation of an Article I court to hear appeals from SSA, VA, and other agencies. Professors Levy ${ }^{227}$ and Bruff ${ }^{228}$ have also suggested such a court that would have jurisdiction over SSA and VA appeals.

\footnotetext{
${ }^{225}$ It was critiqued in Rains, id., and according to Arner, supra note 89 , at 123 , it was shelved after a negative editorial by the New York Times, a letter of opposition to the New York Times from House Judiciary Committee Chairman Peter Rodino, and a resolution of opposition from the ABA.

${ }^{226}$ Remarks Before the Fellow of the American Bar Foundation and the National Conference of Bar Presidents 9-10 (Feb. 15, 1987), cited in Revesz, supra note 55, at 1137.

${ }^{227}$ Levy, supra note 10, at 533 (suggesting the veterans court be transformed into a Court of Disability Appeals).

${ }^{228}$ Bruff, supra, note 55, at 363 .
} 


\section{E. Article III Social Security Court.}

An Article III version of the court proposed by Representative Archer was suggested by the Sloan Foundation Report in $1989 .{ }^{229}$ While the report did not specifically describe the details of the SSC, it would, of course, have life-tenured judges instead of judges with 10-year terms. ${ }^{230}$

F. Article III Specialized Court of Appeals.

1. Jacobs bill H.R. 3265, 103rd Cong. (1993). This bill would consolidate review of all district court decisions in SSA cases in a new Article III United States Court of Appeals for the Social Security Circuit, located in Washington. ${ }^{231}$

2. Jacobs bill H.R. 1587, 104th Cong. (1995). Similar.

\section{$\underline{X . ~ S u m m a r y ~ o f ~ A n a l y s i s ~ a n d ~ R e c o m m e n d a t i o n s ~}$}

\section{A. Pros and Cons of the Present Review System and Alternatives}

\section{The present system}

\section{a. The arguments favoring the present system}

i) It has been in place for a long time and people rely on it.

ii) It is the most independent tribunal possible-Article III district judges give the review system a legitimizing effect.

\footnotetext{
229 Arner, supra note 89, at 117. The Report points out one tactical reason for the earlier proposals for an Article I Social Security Court modeled on the Tax Court-it would remain under the oversight of the House Committee then overseeing Social Security - the powerful House Ways and Means. On other hand, a new Article III court would come within the purview of the Judiciary Committee and it may be that the Judiciary Committee will assume jurisdiction of the Social Security Court as it has over the Tax Court.

230 A possible drawback of making it an Article III court, noted by Arner, would be the ensuing complication in combining it with the Article I veterans court-especially since many of the representatives appearing before the latter court are not attorneys.

${ }^{231}$ Hearings were held on this bill by the House Subcommittee on Social Security of the House Ways and Means Committee on October 21, 1993, but no further action was taken.
} 
iii) It provides a venue in every judicial district and circuit, which makes it more convenient for claimants.

iv) The courts of appeals can review district courts and set national standards.

b. The arguments against the present system

i) It is non-uniform in its decisionmaking and procedures with no assurance that the individual district judges provide decisions that are any more accurate than those of ALJs.

ii) District court decisions have little precedential value.

iii) It is expensive and time consuming:

Social security disability cases comprise 5.86 percent of the federal district court docket in FY 2000.

District courts take eighteen months on average to process a social security disability appeal.

iv) Magistrate judges do much of the actual work, so Article III independence and legitimation is overstated.

2. An Article I court structure with review in the courts of appeals on questions of law and questions arising under the Constitution

a. Arguments in favor of the proposal

i) Uniformity of outcomes is enhanced.

ii) ALJs can be better utilized (i.e., feed-back loops between the court and individual ALJs can be created).

iii) Timelier decisionmaking.

iv) Reduced burden on the federal court system.

b. Arguments against the proposal

i) Independence of an "independent agency" plus an Article I court is still less then that of an Article III court.

ii) Potential loss of geographical convenience 
iii) Would create a larger bureaucracy, unless the Appeals Council is eliminated.

3. An Article III specialized Court of Appeals for Social Security Circuit with review jurisdiction over district court action in social security cases.

a. Arguments in favor of the proposal

i) Systematic oversight of district courts.

ii) Allows for more expert determinations in order to build a system of precedent binding on the agency.

b. Arguments against the proposal

i) Geographically limited, unlike Circuit Courts

ii) Does not really reduce burden on judicial system.

iii) Limited docket may make it harder to find high quality judges.

\section{B. Our Recommendations}

The case for an Article I disability court presents a fascinating question. On the one hand, the present system has the virtue of familiarity; on the other hand, it can certainly be improved. On balance, we think that a shift to an Article I review structure does not just replace one set of problems with another, but would produce real improvements in the system of administrative justice. In drawing this conclusion, we view the CAVC experience with VA disability cases as instructive, but not determinative. Still, the presence of this alternative system, which though imperfect appears workable, makes similar reforms to the social security program seem more workable as well. In our view, SSA has many internal strengths that can make its adoption of a new review structure even more beneficial to all concerned than the record of success produced by the VA disability appeals process. 
Under the current district court review structure, caseloads will increase inexorably and magistrate judges can be expected to determine an increasing percentage of disability cases. The main argument against relieving the district courts of this decision burden is their Article III independence. We believe there are ways to counter this concern within the context of SSA and Article I courts. ${ }^{232}$

With the new status of SSA as an independent agency, there is less of a risk of political control of administrative decisions. ${ }^{233}$ The issue of political control was especially sensitive due to the experience during the Reagan administration's operation of the Continuing Disability Review program, which drove many deserving claimants off the SSA rolls. Although CDRs are now being undertaken on a large number, there is no evidence of the massive terminations that undermined the credibility of that process twenty years ago.

Moreover, as the ABA has recognized, ${ }^{234}$ the independence of SSA also extends to its administrative deciders, the ALJ corps, over 1000 strong. This is an objective source decisionmaking that is lacking at the VA (where non-legally-trained rating boards make initial decisions) and it can be integrated more effectively into an Article I review structure. While more study is needed, the proposal of a two-tier ALJ decision process

\footnotetext{
${ }^{232}$ We put aside any constitutional challenges to this Article I court, for several reasons: first, such a court deals with "public rights" matters, and second, legal and constitutional issues can still be heard in Article III courts. See Commodity Futures Trading Comm'n. v. Schor, 478 U.S. 833, 851-52 (1986) (delegation of even common law counterclaims to an Article I court does not violate Article III); see also Crowell v. Benson, 285 U.S. 22, 50 (1932) (defining public rights).

${ }^{233}$ To further defuse worries about Presidential control of the Social Security Court, members could be required to be appointed like commissioners of independent agencies, with one political party limited to a bare majority.

234 In 1986, the ABA gave an award to the Social Security ALJs for upholding the integrity of administrative adjudication. See Charles Bono, Administrative Report, JUDGES' J., Winter 1992, at 23, 41.
} 
might facilitate error correction, since statistically it can be shown that three (or even

two) judges tend to make more accurate decisions than one alone. ${ }^{235}$

There is, of course, a question whether the ALJ level (even with two tiers) should become the agency's final level of review. The Commissioner may be reluctant to completely give up control over the decision process. Yet, in terms of decision resources, it seems that the Appeals Council is no longer a necessary or even cost-justified step. As noted above, in 1987, after the Administrative Conference conducted a major study of the Appeals Council, ${ }^{236}$ it reported that:

Serious consideration was given to recommending outright abolition of the Appeals Council. This view was premised on the Appeals Council's present inability to do little more than add one more layer to the alreadylengthy review bureaucracy. (This criticism was not intended as a denigration of Appeals Council members, whom the study found to be competent, dedicated, and cooperative.) Before recommending such a drastic, and irreversible step, however, the Conference felt that an attempt should be made to use the unique perspective and expertise of the Appeals Council to help correct the existing problem. The Conference believes that fundamental changes are needed to reduce the Council's caseload to a more manageable volume, so that individual cases can be given more attention and the Council can be a significant contributor to agency policymaking. Accordingly, to implement a system-reform function for the Appeals Council, the Conference makes [a series of $]$ Recommendations for modification of its structure, purpose and operations. $^{237}$

The Conference then formally concluded: "If the reconstituted Appeals Council does not result in improved policy development or case-handling performance within a

\footnotetext{
${ }^{235}$ See MASHAW ET AL, supra note 15 , at 26-27.

${ }^{236}$ The study was published as Charles H. Koch and David A. Koplow, The Fourth Bite at the Apple: A Study of the Operations of the Social Security Administration's Appeals Council, 17 FLA. ST. L. REV. 199 (1990).

237 Administrative Conference of the U.S., A New Role for the Social Security Appeals Council, Recommendation 87-7 I[2, available at http://www.law.fsu.edu/library/admin/acus/305877.html. See text at note 16 , supra.
} 
certain number of years (to be determined by Congress and SSA), serious consideration should be given to abolishing it.",238

In the intervening time, it appears that the Appeals Council's caseload has not been reduced and its policy making function has not been enhanced. Therefore, it may be time to consider the reforms suggested herein—moving to a Social Security Court and allowing a reconstituted ALJ stage to be the final "bite at the apple" at SSA.

The proposal for a SSC, drafted by the Department of Justice in 1985-86 (see Part IX(A)(9), above), provided for a court of 37 members that had offices in five regions around the country. This number still seems about right. The Court of Appeals for Veterans Claims provides a basis for comparison. It has seven judges (temporarily raised to nine). In 1999, it received 2,442 filings, and there were 14,881 affirmances of denied claims by the BVA in that same year. The SSA Appeals Council, in FY 2000, made about 97,000 decisions that were unfavorable to claimants. This is about 6.5 times as many potential appeals to the SSC as compared to the CAVC. A similar ratio would be derived by comparing the 15,829 SSA appeals in the district courts in FY 2000 to the 2,442 filings in the CAVC in 1999. Based on these comparisons, the number of judges on an SSC should be around $45 .^{239}$

These figures reflect the much higher percentage (59 percent) of rulings that are favorable to claimants (reversals and remands) at the BVA as compared to 29 percent at the Appeals Council. But if a two-tier ALJ process were made the final arbiter at SSA instead of the Appeals Council, changes in the SSC's potential caseload could ensue as

\footnotetext{
${ }^{238} I d$., preamble.

239 The SSC could decide cases in a two-tier (precedential/non-precedential; one judge/three judge) system as the CAVC and the bankruptcy courts do.
} 
well. On the one hand, it might lead to a more modulated level of claimant appeals if they were allowed two levels of review before independent ALJs. ${ }^{240}$ On the other, SSA might be given the right to seek review by the SSC as well.

Regardless of the size of the SSC, the DOJ proposal for geographically distributed regional offices makes sense to address the important issue of access to the courthouse.

We also believe that appeals from the SSC should be to the geographic circuits, (like the Tax Court) in order to preserve some diversity on questions of law. However, judicial review to the courts of appeals should be limited to legal issues-the validity or interpretations of statutes or regulations and constitutional issues. Article III court appellate jurisdiction of these issues is essential, for constitutional reasons and for developing precedent and important legal questions. On the other hand, fact-based review in the court of appeals is of limited value in terms of good faith error correction. ${ }^{241}$ Class actions and facial constitutional challenges could be preserved in district courts, with direct rule challenges going directly to the courts of appeals.

If, as we recommend, SSA should be entitled to appeal from initial ALJ decisions to the SSC, this change would lead to true adversarial hearings before ALJs with the government being represented.

Finally, making the SSA court an Article I rather than Article III court has two further advantages: it would not be necessary to create more life-tenured judges; and it

\footnotetext{
${ }^{240}$ As Professor Levy acknowledges in connection with his proposal, "[t]he extent to which independent administrative review will screen out cases in difficult to predict. It will depend to some degree on the faith which claimants have in the objectivity of administrative decisions." Levy, supra note 10 at 514, n. 294.

${ }^{241}$ See $i d$., at 514-515 (arguing for limited review in the court of appeals). Professor Levy recommends centralizing appellate review in the Court of Appeals for the Federal Circuit. We prefer to retain jurisdiction in the geographic circuits. Professor Levy carefully addresses the constitutionality of limiting fact-based review to the Article I court at 517-525.
} 
would also make it easier, ultimately, to combine the SSA court with the CAVC should it be decided in the future to create an overarching Disability Court.

In conclusion, although we do not favor the proposed Article III specialized court of appeals, we do favor serious consideration of an Article I Social Security Court.

\section{Next Steps}

Whatever happens with the judicial review proposal, we believe several steps can and should be taken at the SSA level. First, the use of attorneys for the government requires further consideration (costs, qualifications, etc.). ${ }^{242}$ Second, consideration should be given to the long pending suggestion of closing the file at the ALJ stage. Third, amending the "good cause" remand provision of section 205(g) should also be considered (so as to reduce the ease of remand at the district court).

Finally, we believe much can be done to better utilize and improve the performance of ALJs in the disability decision process, separate from the Article I court idea. An ALJ appeals process (using two or three ALJs to review their colleagues' decisions in precedential or other selected cases) $)^{243}$ could aid uniformity and correctness, and, if it works well, could take over the error correction and quality review functions now performed by the Appeals Council. The resources currently spent on the Appeals Council (reportedly over $\$ 64$ million in FY 2000) ${ }^{244}$ could be used to cover the additional

\footnotetext{
${ }^{242}$ This would presumably also lead to coverage by the Equal Access to Justice Act, concerning payment of attorney fees, because the cases would then fit the definition of "adversary adjudication" under the Act. See Statement by Stanford G. Ross, Chairman, Social Security Advisory Board, at the Tenth National Educational Conference Association of Administrative Law Judges (Oct. 3, 2001) available at http://www.ssab.gov/rossstatemtaljconf.pdf; see also SSAB, CHARTING THE FUTURE, supra note 21, at 1920 (calling for the SSA to be represented at ALJ hearings because the claimants are represented).

${ }^{243}$ Selection of ALJs to serve on the reviewing panels could be made by the regional chief ALJs at the SSA.

${ }^{244}$ REPORT ON NEW INDEPENDENT REGULATORY AGENCY, supra note 10, at 4 (citing the SSA Fiscal Year 2000 Performance and Accountability Report's figure of \$64,671,200).
} 
ALJs needed for the two tier review. Additionally, some Appeals Council members might be considered for positions as ALJs or as members of the Social Security Court. Moreover the SSA should use some of these resources to improve its policymaking through rulemaking.

It is beyond the scope of this Report to assess the current effectiveness of SSA's rulemaking, but we believe that many of the Appeals Council's resources could be profitably redeployed to this effort.

We are prepared to assist in exploring these and other initiatives and alternatives, if called upon by the SSAB. 
Appendix A.

Allowance rates by district for the 48 district courts with at least 100 SSA appeals ordered by their allowance rates. ${ }^{245}$

\begin{tabular}{|c|c|c|c|c|c|}
\hline District & $\begin{array}{c}\text { Number } \\
\text { of cases } \\
\text { terminated }\end{array}$ & $\begin{array}{l}\text { Number of } \\
\text { judgments on } \\
\text { the merits }\end{array}$ & $\begin{array}{l}\text { Percentage of } \\
\text { judgments on } \\
\text { the merits won } \\
\text { by claimant }\end{array}$ & $\begin{array}{l}\text { Number of } \\
\text { judgments for } \\
\text { the claimants }\end{array}$ & $\begin{array}{l}\text { Allowance } \\
\text { Rate }^{246}\end{array}$ \\
\hline NYND & 104 & 13 & 0.0 & 0 & 0 \\
\hline TXND & 170 & 24 & 0.0 & 0 & 0 \\
\hline KYED & 727 & 132 & 2.3 & 3 & 0.41 \\
\hline KYWD & 176 & 48 & 2.1 & 1 & 0.57 \\
\hline OKND & 169 & 39 & 2.6 & 1 & 0.59 \\
\hline LAWD & 148 & 14 & 7.1 & 1 & 0.68 \\
\hline LAED & 118 & 19 & 5.3 & 1 & 0.85 \\
\hline OHND & 437 & 62 & 6.5 & 4 & 0.92 \\
\hline CAND & 188 & 48 & 4.2 & 2 & 1.06 \\
\hline PAED & 283 & 57 & 5.3 & 3 & 1.06 \\
\hline VAWD & 369 & 88 & 5.7 & 5 & 1.36 \\
\hline MIWD & 131 & 34 & 5.9 & 2 & 1.53 \\
\hline NM & 183 & 21 & 14.3 & 3 & 1.64 \\
\hline PR & 167 & 35 & 8.6 & 3 & 1.80 \\
\hline TXED & 158 & 10 & 30.0 & 3 & 1.90 \\
\hline ALMD & 103 & 7 & 28.6 & 2 & 1.94 \\
\hline $\mathrm{NJ}$ & 293 & 20 & 30.0 & 6 & 2.05 \\
\hline TNED & 305 & 84 & 8.3 & 7 & 2.30 \\
\hline WVSD & 298 & 149 & 4.7 & 7 & 2.35 \\
\hline INSD & 116 & 41 & 7.3 & 3 & 2.59 \\
\hline CACD & 605 & 160 & 10.0 & 16 & 2.64 \\
\hline TXSD & 164 & 54 & 9.3 & 5 & 3.05 \\
\hline NCMD & 160 & 83 & 6.0 & 5 & 3.13 \\
\hline $\mathrm{SC}$ & 363 & 78 & 19.2 & 15 & 4.13 \\
\hline TXWD & 111 & 31 & 16.1 & 5 & 4.50 \\
\hline NYWD & 131 & 31 & 19.4 & 6 & 4.58 \\
\hline $\mathrm{MD}$ & 306 & 79 & 17.7 & 14 & 4.58 \\
\hline
\end{tabular}

245 Theodore Eisenberg \& Kevin M. Clermont, Judicial Statistical Inquiry Form: Federal District-Court Civil Case, supra note 47 (providing a dataset that displays the total number of SSA appeals, the number of cases terminated on the merits and the plaintiff's win rate), at http://teddy.law.cornell.edu:8090/questcv3.htm.

246 The allowance rate divides the number of judgments for the claimants (ordering payments without remand) into the total number of cases terminated. Of course, the actual allowance rate after the district court level will be higher because claimants are ultimately awarded benefits in the majority of remands. 


\begin{tabular}{|c|c|c|c|c|c|}
\hline WAWD & 147 & 15 & 46.7 & 7 & 4.76 \\
\hline FLSD & 143 & 47 & 17 & 8 & 5.59 \\
\hline CASD & 110 & 43 & 16.3 & 7 & 6.36 \\
\hline CAED & 176 & 41 & 29.3 & 12 & 6.82 \\
\hline ILND & 109 & 40 & 20 & 8 & 7.34 \\
\hline OHSD & 311 & 121 & 19.8 & 24 & 7.72 \\
\hline MIED & 275 & 186 & 12.4 & 23 & 8.36 \\
\hline MOWD & 229 & 70 & 28.6 & 20 & 8.73 \\
\hline FLMD & 639 & 137 & 41.6 & 57 & 8.92 \\
\hline PAWD & 280 & 147 & 17 & 25 & 8.93 \\
\hline ALSD & 157 & 42 & 38.1 & 16 & 10.19 \\
\hline OR & 188 & 52 & 44.2 & 23 & 12.23 \\
\hline NYED & 389 & 87 & 59.8 & 52 & 13.37 \\
\hline ARED & 355 & 184 & 26.1 & 48 & 13.52 \\
\hline GAMD & 194 & 107 & 29 & 31 & 15.98 \\
\hline GAND & 269 & 108 & 50 & 54 & 20.07 \\
\hline ARWD & 130 & 66 & 48.5 & 32 & 24.62 \\
\hline NYSD & 305 & 158 & 53.8 & 85 & 27.87 \\
\hline OKED & 110 & N/A & N/A & $\mathrm{N} / \mathrm{A}$ & $\mathrm{N} / \mathrm{A}$ \\
\hline OKWD & 131 & N/A & N/A & $\mathrm{N} / \mathrm{A}$ & $\mathrm{N} / \mathrm{A}$ \\
\hline ALND & 413 & N/A & N/A & $\mathrm{N} / \mathrm{A}$ & N/A \\
\hline TOTAL & 13681 & 3849 & 21.85 & 841 & (6.15 \\
\hline $\begin{array}{l}\text { AVERAGE } \\
247\end{array}$ & 150.3 & 44.24 & 21.85 & 9.66 & 6.15 \\
\hline
\end{tabular}

247 The average number of cases terminated is given for all 91 district courts, and not just the ones displayed in the table. The average for the number of judgments on the merits, the percentage of judgments for the claimants, the number of judgments for the plaintiffs and the allowance rate are given for the 87 districts reporting these statistics. In addition to the three districts without data in the table, the district court for Arizona does not submit statistics. 


\section{Appendix B. \\ DI and SSI Disability \\ Determinations and Appeals*}

Fiscal Year 2000

Initial Level

$1,988,425$

Reconsiderations

$\mathbf{5 8 4 , 5 4 0}$

ALJ Dispositions

433,584

Appeals Council

122,780 **

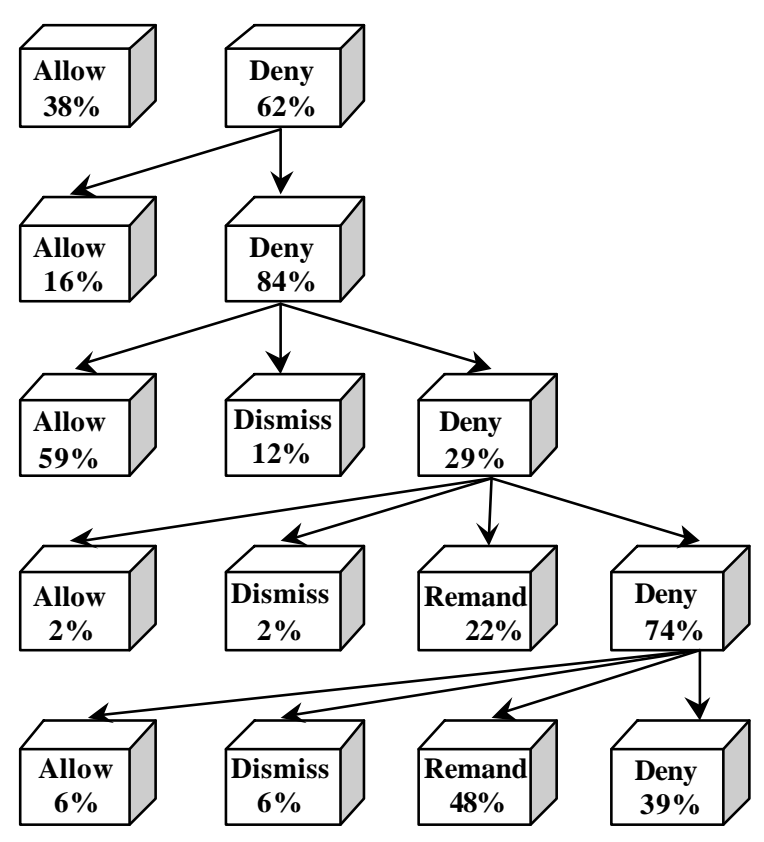

Federal Court

Decisions $* * *$

12,011

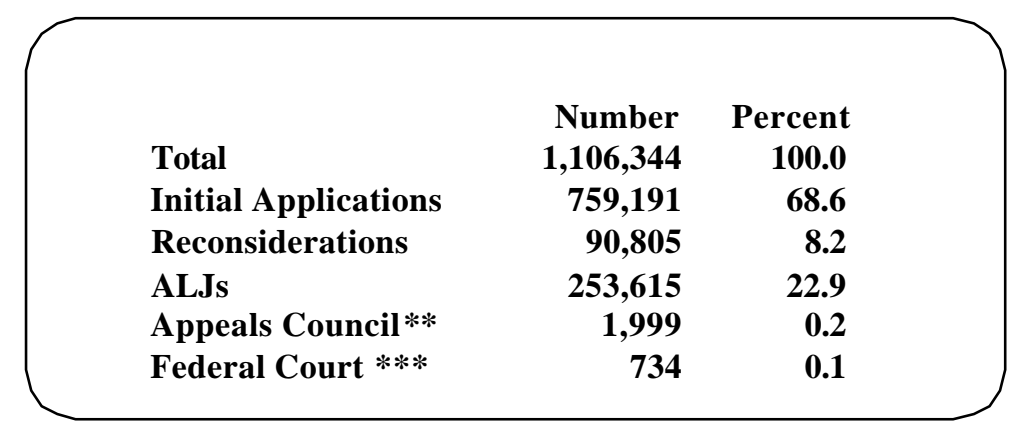

* Data relate to workloads processed (but not necessarily received) in fiscal year 2000, i.e., the cases processed at each adjudicative level may include cases received at 1 or more of the lower

adjudicative levels prior to fiscal year 2000. Not all denials are appealed to the next level of review.

** Includes ALJ decisions not appealed further by the claimant but reviewed by the Appeals Council on "own motion" authority.

*** Remands to ALJs by the Appeals Council and Courts result in allowances in about 60 percent of the cases.

Source: Social Security Advisory Board, Disability Decision Making: Data and Materials, January 2001. 